\title{
Valuable Biomolecules from Nine North Atlantic Red Macroalgae: Amino Acids, Fatty Acids, Carotenoids, Minerals and Metals
}

\author{
Behnaz Razi Parjikolaei1 ${ }^{*}$, Annette Bruhn², Karin Loft Eybye3 ${ }^{3}$, Martin Mørk Larsen", \\ Michael Bo Rasmussen ${ }^{2}$, Knud Villy Christensen' ${ }^{1}$, Xavier C. Fretté1 \\ ${ }^{1}$ Department of Chemical Engineering, Biotechnology and Environmental Technology, University of Southern \\ Denmark, Odense, Denmark \\ ${ }^{2}$ Department of Bioscience, Aarhus University, Silkeborg, Denmark \\ ${ }^{3}$ Food Technology Department, Life Science Division, Danish Technological Institute, Aarhus, Denmark \\ ${ }^{4}$ Department of Bioscience, Aarhus University, Roskilde, Denmark \\ Email: ${ }^{*}$ bep@kbm.sdu.dk
}

Received 18 January 2016; accepted 15 April 2016; published 18 April 2016

Copyright (C) 2016 by authors and Scientific Research Publishing Inc.

This work is licensed under the Creative Commons Attribution International License (CC BY).

http://creativecommons.org/licenses/by/4.0/

(c) (i) Open Access

\section{Abstract}

In modern society, novel marine resources are scrutinized pursuing compounds of use in the medical, pharmaceutical, biotech, food or feed industry. Few of the numerous marine macroalgae are currently exploited. In this study, the contents of nutritional compounds from nine common North Atlantic red macroalgae were compared: the lipid content was low and constant among the species, whereas the fatty acid profiles indicated that these species constitute interesting sources of polyunsaturated fatty acids (PUFA). The dominating essential and non-essential amino acids were lysine and leucine, aspartic acid, glutamic acid, and arginine, respectively. The amino acid score of the nine algae varied from $44 \%$ to $92 \%$, the most commonly first limiting amino acid being histidine. Lutein, $\beta$-carotene, and zeaxanthin were the identified carotenoids. Contents of all macro and trace minerals, with the exception of phosphorus, were higher than those described for conventional food. Low sodium/potassium ratios $(0.08-2.54)$ suggested a potential for using the ash fraction for sodium salt replacement. The algae constituted rich sources of carbohydrates $(40 \%$ to $71 \%$ of DM) which show their potential for a broader commercial exploitation. In some species, the concentrations of arsenic, cadmium, and lead exceeded limit values for application in food or feed. In conclusion, the nine algae represent promising potential sources of health promoting additives for human and animal diets, in whole or in a biorefinery concept.

\footnotetext{
"Corresponding author.
}

How to cite this paper: Razi Parjikolaei, B., Bruhn, A., Eybye, K.L., Larsen, M.M., Rasmussen, M.B., Christensen, K.V. and Fretté, X.C. (2016) Valuable Biomolecules from Nine North Atlantic Red Macroalgae: Amino Acids, Fatty Acids, Carotenoids, Minerals and Metals. Natural Resources, 7, 157-183. http://dx.doi.org/10.4236/nr.2016.74016 


\section{Keywords}

\section{Protein, Lipid, Carotenoids, Dry Matter, Arsenic}

\section{Introduction}

In modern society attention is directed towards new and unexploited marine resources in pursuit of compounds of use in the medical, pharmaceutical, biotech, food or feed industry. Marine macroalgae contain an unknown number of bioactive compounds, of which a limited fraction has yet been discovered, investigated and characterized, and even less commercially exploited [1] [2]. Among macroalgae, red macroalgae are the most diversified with the largest number of species, counting approximately 4000 species on a global scale [3]. Red algae are sources of various known valuable biomolecules such as proteins, peptides, amino acids, pigments, antioxidants, as well as hydrocolloids [2] [4]-[7]. A few species of red algaeare are currently exploited in the food industry, either serving as food directly (nori and dulse) or as raw material for the production of gelling agents (phycocolloids) such as agar and carrageenan [6]. With the increased global demand for proteins, as well as functional food ingredients, the interest in red algae is expected to increase. Among the macroalgae, the red algae generally hold high protein concentrations [2] [8]. For instance, the protein content of Palmaria palmata and Porphyra tenera can represent up to $35 \%$ and $44 \%$ of DM, respectively [8] [9]. These levels are comparable to protein contents found in protein-rich legumes such as soybeans (35\% of DM) [10]. However, not only protein quantity, but also protein quality is of importance, and the Amino Acid (AA) composition of macroalgae is attractive, also for animal feed production, since in particular the content of sulphated AAs, such as methionine, is higher in algae than in plant proteins [11]. Another class of biomolecules of nutritional value from macroalgae is the essential $\omega 3$ fatty acids, which are composed of long-chain PUFAs. Presently, the most common source of long chain PUFAs for nutraceuticals and feed is fish oil [12]. Viewed in the light of the rapid decrease in the world fish populations, alternative sources of $\omega 3$ fatty acids, such as marine macro- and microalgae must be exploited [13] [14]. Recent market research estimated the global demand for $\omega 3$ ingredients to be about $\$ 1.56$ billion in 2010, expected to reach $\$ 4$ billion in 2018. In addition to the long chain fatty acids, macroalgae are important sources of carotenoids which are natural red, orange, and yellow pigments comprising a complex class of hydrocarbons (carotenes such as $\alpha$ - and $\beta$-carotene) and their oxygenated derivatives (xanthophylls, such as astaxanthin, fucoxanthin, lutein and zeaxanthin) [2]. Carotenoids are known for their anti-cancer, antioxidant properties and activity against obesity which makes them an attractive class of high-value compounds [1] [15]. Industrially, carotenoids are used in pharmaceuticals, animal feed as well as colorants in cosmetics and foods [16]. Moreover, carotenoids are utilized in aquaculture feed and are responsible for pigmentation of muscle in fish for consumption and skin color in ornamental fish [17] [18]. The current market value of commercially used carotenoids was estimated at nearly $\$ 1.2$ billion in 2010 which with an annual growth rate of $2.3 \%$ has the potential to reach $\$ 1.4$ billion in 2018 [19]. Macroalgae are described as valuable sources of minerals for human and animal nutrition, with higher concentrations of essential macro minerals (i.e. $\mathrm{K}, \mathrm{Ca}, \mathrm{Na}$ ) and trace elements (i.e. $\mathrm{Fe}, \mathrm{Cu}, \mathrm{Zn}$ ) than terrestrial plants [4] [20]-[22].

The main tissue component of macroalgae is typically carbohydrates, serving as structural components of the cell walls as well as for energy storage [23]. Nutritionally, carbohydrate is the most important class of compounds for the metabolism as carbohydrates supply the majority of the energy (35\% - 70\%) needed for respiration and other metabolic processes in all living organism. However, red macroalgae constitute a rich source of unique polysaccharides with bioactive properties [1], and already specific sulphated polysaccharides e.g. agar, carrageenan, furcellaran and floridian starch, are being commercially exploited for their gelling properties [6].

The North Atlantic macroalgae species Chondrus crispus is traditionally applied for production of carrageenan, a highly sulfated polysaccharide [24]. The cold water species contain specific types of carrageenan, that are not available from the cultivated warm water carrageenophytes, Kappaphycus alvarezii (Cottonii) and Eucheuma denticulatum (Spinosum) and thus they are of relatively high value [6]. Gracilaria sp. is one of the two most important agarophytes in the world [6]. The global market for hydrocolloids is increasing, in particular within the food industry, and the industry calls for innovation within algae cultivation and breeding as well as a broadening of the selection of species exploited [6]. 
The wealth of attractive biomolecules in marine macroalgae drives an increasing number of patent applications on specific uses of macroalgae in particular in the food, agri- and aquaculture, and human health industries. The increase in patent claims, as well as in seaweed production, is clearly skewed towards the Asian countries where seaweed consumption and cultivation have deeper cultural roots than in Western countries. However, western countries giving priority to biotechnology investments are also moving forward in the field of patent applications and scientific work on novel applications and cultivation of seaweed. North Atlantic waters offer a rich potential of already exploited as well as unexploited species of red macroalgae. As an example, in the Inner Danish waters, at the transition zone between the North Sea and the Baltic Sea, up to 422 species of macroalgae are described [25].

In the present work, the objective was to map the content of nutritionally attractive biomolecules of nine common species of North Atlantic red algae species to gain extensive information about their nutritional value and evaluate their applicability in human food, as well as in animal diet. The aspects of minerals in the context of nutrition, as well as metals in the context of food safety were also discussed. The nine species reported to contain high value biomolecules were selected. Here of two known "bench mark species" Palmaria palmata (Linnaeus) Kuntze and Chondrus crispus (Stackhouse) were chosen to compare with seven relatively undescribed species, covering different phylogeny and morphology, but still fulfilling a criteria of general availability, accessibility, and robustness as seeding stock for potential future cultivation.

\section{Material and Methods}

\subsection{Algae Samples}

Nine species of red macroalgae were selected: Delesseria sanguinea (Hudson) J.V. Lamouroux, Dilsea carnosa (Schmidel) Kuntze, Odonthalia dentata (Linnaeus) Lyngbye, P. palmata, Phycodrys rubens (Linnaeus) Batters, C. crispus, Furcellaria lumbricalis (Hudson) J. V. Lamouroux, Gracilaria vermiculophylla (Ohmi) Papenfuss, and Ahnfeltia plicata (Hudson) E. M. Fries (Table 1). Fresh algae were collected between the $15^{\text {th }}$ and $19^{\text {th }}$ of September 2011 by scuba diving at depths between 0 and 5 meters. G. vermiculophylla was collected in Horsens Fjord, Denmark (N55 $52^{\prime} 43$, E09 ${ }^{\circ} 59^{\prime} 12$ ), while the remaining eight species were collected at Fornæs, Denmark (N56 ${ }^{\circ} 26^{\prime} 35$, E09 $\left.59^{\prime} 12\right)$. Species identification was based on 25 years of experience with taxonomy of Danish algae, and Rosenvinge $(1909,1918,1931)$. Samples were transported to the laboratory in fresh, cool seawater.

Table 1. Species, family, compounds (and bioactivities) of interest, growth rate and global distribution of the studied red algae.

\begin{tabular}{|c|c|c|c|c|}
\hline Algal species & Family & Compound (bioactivity) & Growth rate1 (\% d-1) & Distribution2 \\
\hline Ahnfeltia plicata (Ap) & Ahnfeltiaceae & Agar $^{4}$ & n.d. ${ }^{3}$ & NA, SA, NP, SP, AO \\
\hline Chondrus crispus (Cc) & Gigartinaceae & Carrageenan, $\beta$-carotene ${ }^{5}$ & $1.5-2.6(\% \text { week- } 1)^{11}, 6^{12}$ & NA, BS \\
\hline Delesseria sanguinea (Ds) & Delesseriaceae & $\begin{array}{l}\text { Sulphated polysaccharide } \\
\text { (anti-inflammatory) }^{6}\end{array}$ & $1^{13}$ & NA, BS \\
\hline Dilsea carnosa (Dc) & Dumontiaceae & $(\text { Anti-fungal })^{7}$ & n.d. & NA, NP, BS \\
\hline Furcellaria lumbricalis (Fl) & Furcellariaceae & Furcellaran & $1.1 \quad 2.7^{14}$ & NA, BS, IO \\
\hline Gracilaria vermiculophylla (Gv) & Gracilariaceae & $\begin{array}{l}\text { Agar }^{5} \text {, lectin, tocopherol, } \\
\text { phycobiliproteins }^{5}\end{array}$ & $6^{15}$ & NA, NP, MS, SP, \\
\hline Odonthalia dentata (Od) & Rhodomelaceae & (Anti-fungal) $^{7}$ & n.d. & NA, AO, NP \\
\hline Palmaria palmata (Pp) & Palmariaceae & $\begin{array}{c}\text { Protein }^{5} \text {, xylans } \\
\end{array}$ & $8.9^{16}$ & NA, SA, NP, SP, AO, BS \\
\hline Phycodrys rubens (Pr) & Delesseriaceae & Sterols $^{1}$, Carotenoids ${ }^{18}$ & $0.1^{16}, 1-2^{17}$ & NA, NP, BS \\
\hline
\end{tabular}

${ }^{1}$ Growth rate refers to cultivation in landbased or laboratory systems; ${ }^{2}$ Distribution is based on Algaebase (http://www.algaebase.org). NA: North Atlantic Ocean, SA: South Atlantic Ocean, NP: North Pacific Ocean, SP: South Pacific Ocean, BS: Baltic Sea, IO: Indian Ocean, MS: Mediterranean Sea, AO: Arctic Ocean; ${ }^{3}$ n.d. no data; ${ }^{4}$ Mansilla et al. [107]; ${ }^{5}$ Holdt \& Kraan [2]; ${ }^{6}$ Grünewald et al. [134]; ${ }^{7}$ Tariq [135]; ${ }^{8}$ Lahaye \& Vigouroux [136]; ${ }^{9}$ Mouritsen et al. [36]; ${ }^{10}$ Dauguet [137]; ${ }^{11}$ Bidwell [110]; ${ }^{12}$ Corey et al. [114]; ${ }^{13}$ Potin [138]; ${ }^{14}$ Martin et al. [139]; ${ }^{15}$ Abreu et al. [118]; ${ }^{16}$ van de Poll [140]; ${ }^{17}$ Gordillo [141]; ${ }^{18}$ Razi Parjikolaei personal communication. 
In the laboratory, the samples were thoroughly rinsed in fresh water, carefully wiped dry with paper tissue and stored until analysis at $-20^{\circ} \mathrm{C}$. Subsamples of all algae samples were freeze-dried (European Freeze Dry ApS, Denmark) and ground through a $1 \mathrm{~mm}$ sieve using a Retsch ultra centrifugal mill (Type ZM1) (SkanLab, Denmark). The powdered samples were stored at $-20^{\circ} \mathrm{C}$ until further analysis.

\subsection{Analytical Methods}

\subsubsection{Dry Matter and Ash}

The DM content was determined by weighing the difference in mass before and after the freeze-drying process and expressed in grams per 100 grams of fresh material. Regarding the ash analysis, a known amount of sample was weighed before and after incineration at a temperature of $525^{\circ} \mathrm{C}$ for 16 hours (Nordisk Metodikkomité for Levnedsmidler (NMKL) 173:2005). The result was expressed as the percentage of ash in algae DM.

\subsubsection{Nitrogen and Protein}

The total amount of nitrogen $(\mathrm{N})$ was measured according to two methods, the Kjeldahl method as well as by the Pregl-Dumas (Leco's CNS 2000, USA) ignition in pure oxygen atmosphere, followed by chromatographic separation of carbon $(\mathrm{C})$, hydrogen $(\mathrm{H})$ and nitrogen $(\mathrm{N})$ with detection of the individual elements by thermal conductivity [26]. All analyses were performed according to Danish Accreditation no. 411, with certified reference material BCR 279 for CHN analysis used for verification of analytical quality. Recently, a global conversion factor to be used for protein estimation in macroalgae has been suggested to be five [27], however, in order to compare the crude protein content of the algae studied in the present work with values of other studies, the amount of crude protein was calculated using a conversion factor of 6.25 (NMKL 6.4, 2003 mod). The content of inorganic $\mathrm{N}$ was calculated by subtracting the total Kjeldahl $\mathrm{N}(\mathrm{TKN})$ from the total $\mathrm{N}$ (TN) value of the Dumas method [28].

\subsubsection{Amino Acids}

The determination of AAs was done according to the EU 152/2009 (A) and ISO 13903:2005 methods. In brief, $200 \mathrm{mg}$ of algae powder was oxidized at $0^{\circ} \mathrm{C}$ with a hydrogen peroxide (Merck, Darmstadt, Germany)/formic acid (VWR, Fontenay-sous-Bois, France). The oxidized sample was hydrolyzed with a mixture of $6 \mathrm{M}$ hydrochloric acid (Chemsolute, Th. Geyer, Roskilde, Denmark) and 0.1\% phenol (Merck, Darmstadt, Germany) at $110^{\circ} \mathrm{C}$ for 23 hours and the hydrolyzates were adjusted to $\mathrm{pH}$ 2.2. The AAs were separated by Biochrom 30 (Bie \& Berntsen A/S, Herlev, Denmark), an ion exchange chromatography system using post column derivatization with ninhydrin with a photometric detection at $570 \mathrm{~nm}$ (440 $\mathrm{nm}$ for proline).

Identification and quantification of the individual AAs was done by comparing the retention time and peak area with standards (Sigma-Aldrich, Munich, Germany) and the area of the internal standard norleucine using the Biochrom BioSys software. Cystine and cysteine were oxidized to cysteic acid and calculated as the sum of both cysteine equivalents. To compensate for loss due to hydrolyzation, the tyrosine concentration was corrected by a factor of 1.19. Tryptophan was destroyed during hydrolyzes and a specific procedure for detection of tryptophan was not applied. Amino acid content was expressed as percent of total AA. The AA results were furthermore converted to $\mathrm{g} / 100 \mathrm{~g}$ protein content calculated based on the Kjeldahl method.

Essential AAs (EAAs) were compared with AA requirement for 3 - 14 years school child/adolescent [29] and calculated by the updated method of WHO/FAO/UNU as shown below:

$$
\text { Amino acid score }(\%)=\frac{(\mathrm{mg} \text { most limiting amino acid per } \mathrm{g} \text { of test protein } \times 100)}{(\mathrm{mg} \text { limiting amino acid per } \mathrm{g} \text { of reference protein pattern })}
$$

The essential amino acid index (EAAI) compares the protein quality and is more associated with the biological quality of a protein than the AA score. It is calculated as the geometric mean value of the ratios for EAA (Ile, Leu, Lys, Met+Cys, Phe+Tyr, Thr, Val, and His), and values above 100 are considered as 100 [30].

\subsubsection{Total Lipid}

The freeze-dried samples were hydrolyzed using ethanolic 12 M hydrochloric acid (Chemsolute, Th. Geyer, Roskilde, Denmark/ethanol 96\%, Kemethyl, Køge, Denmark). After drying the sample, fat was subsequently extracted with a mixture of diethyl ether (Sigma-Aldrich A/S, Copenhagen, Denmark) and petroleum ether 
(Sigma-Aldrich A/S, Copenhagen, Denmark). The extract was concentrated and weighed according to the Schmid-Bondzynski-Ratzlaff (SBR) principle (Nordisk Metodikkomité for Levnedsmidler (NMKL) 131:1989, mod). The result was expressed as the percentage of lipids in algae DM.

\subsubsection{Fatty Acids}

The FA composition was obtained by extracting lipids from powdered samples by the Schmid-Bondzynski-Ratslaff (SBR) method (NMKL 131: 1989). The FAs were then derivatized with sodium methylate (IUPAC 2301), and the derivatized samples (fatty acid methyl esters) were analyzed using gas chromatography with flame ionization detector (GC-FID) (AOCS Ce 1h-05). The equipment was a GC-FID Agilent 7890A system (Glostrup , Denmark) and separation was performed on a Omegawax ${ }^{\mathrm{TM}}$ column (length $30 \mathrm{~m}$, internal diameter $0.25 \mathrm{~mm}$ and film thickness $0.25 \mu \mathrm{m}$ ) (Supelco, \#24136, Sigma-Aldrich A/S, Copenhagen, Denmark). The inlet temperature was $250^{\circ} \mathrm{C}$ and detector temperature $260^{\circ} \mathrm{C}$. Oven temperature was initially at $50^{\circ} \mathrm{C}$ for one minute, and then ramped $20^{\circ} \mathrm{C} \mathrm{min}{ }^{-1}$ to $170^{\circ} \mathrm{C}$, followed by $1^{\circ} \mathrm{C} \mathrm{m^{-1 }}$ to $225^{\circ} \mathrm{C}$, and held at $225^{\circ} \mathrm{C}$ for 5 minutes. Total runtime was 67 minutes. Volume injected: one $\mu \mathrm{L}$ with a split ratio of 100:1. Identification and concentration of FAs was determined by retention times and comparison of peak areas with pure standards, GLC744, GLC411 (Nu- Check Prep, Elysian, USA) and PUFA-3 (Sigma-Aldrich A/S, Copenhagen, Denmark). Fatty acid concentrations were expressed as percentage of the total area of all FA peaks $(O$. dentata was excluded from this analysis due to the low sample volume available).

\subsubsection{Carbohydrate}

Total carbohydrate content in percentage was estimated by subtracting the sum of lipid, protein, and ash values from $100 \%$ of DM. Contents of carbohydrate were expressed as the percentage of algae DM.

\subsubsection{Carotenoids}

Extraction and identification of the carotenoids was carried out as described by Razi Parjikolaei et al. [31]. During high performance liquid chromatography (HPLC) (Agilent 1200 series, Glostrup, Denmark) analysis, peak assignment was performed by comparing the retention times and line spectral properties obtained from photodiode array detection with standards of fucoxanthin (Sigma-Aldrich A/S, Copenhagen, Denmark), zeaxanthin, lutein and $\beta$-carotene (Extrasynthese, Genay, France). For precise carotenoid identification, analyses of the extracts were also performed with the same column and eluting conditions with an HPLC hyphenated with a mass spectrometer (Accela LTQ ion trap XL ETD, Thermo Scientific ${ }^{\mathrm{TM}}$, Waltham, MA, USA). The LC-MSMS method was similar to the one described by Gentili and Caretti [32]. All solvents were of HPLC grade (VWR Prolabo, Herlev, Denmark).

\subsubsection{Elemental Analysis}

A sub-sample of $0.4 \mathrm{~g}$ of the freeze-dried and homogenized algae was taken for microwave digestion in closed

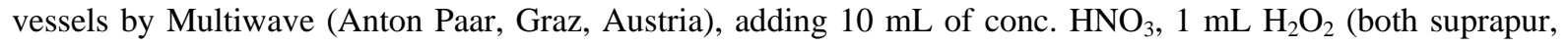
Merck, Darmstadt Germany) and $10 \mathrm{~mL}$ of Milli-Q water ( $>18 \mathrm{MOhm})$. After digestion, each sample was transferred into a pre-weighed polyethylene jar. Eighty $\mathrm{mL}$ Milli-Q water was added and the jar weighed again to calculate the dilution. Metal concentrations were quantified using an Inductively Coupled Plasma-Mass Spectrometry (ICP-MS) 7500 cs (Agilent, USA) with a Babington nebulizer connected to a cooled spray chamber $\left(5^{\circ} \mathrm{C}\right)$. The mist was introduced into an argon (Ar) plasma operating at $1.500 \mathrm{~W}$ with $15 \mathrm{~L}$ Ar per minute. The plasma ionized metals were passed through an off-axis ion lens system and an Octopole Reaction Cell (ORC) in three passes with either Hydrogen, Helium or no gas to minimize interferences from multielement interferences (e.g. Ar-Cl on As), before final detection using quadropole mass spectrometer. Standard mass-overlap correction from the US Environmental Protection Agency (USEPA) method 6020 was used to correct 75 arsenic (As) and 111 cadmium (Cd). External calibration was performed on the corrected ion counts. During the run, drift was corrected by using a pumped solution of $100 \mathrm{ppb}$ rhodium (Rh) and indium (In) (both Johnson Matthey, Alfa product, MA, USA) and 500 ppb germanium (Ge) (SCP science, Quebec, Canada). The optimum combination of internal standard and ORC gas was used for all elements. For Cd and $\mathrm{Zn}$, determinations were based on atomic absorption spectrometry. Zn was determined using acetylene-air flame atomic absorption and finally Cd using transversally heated graphite furnace atomic absorption both on Perkin Elmer 3300 (PerkinElmer Inc., MA, USA). All analyses were performed according to Danish Accreditation no. 411, with certified reference 
material IAEA 140 for ICP-MS analysis used for verification of analytical quality.

\subsection{Presentation of Data and Statistical Analysis}

All analyses of carotenoids, elements, and the Dumas nitrogen were carried out on triplicate biological samples and data was presented as average \pm standard error (SE). All other analyses had to be carried out as single or double samples due to the limited amount of sample available. Relative expanded uncertainty of the applied methods for analyzing the lipid, DM, ash, protein (Kjeldahl method), as well as FA and AA reported are based on a standard uncertainty of each method multiplied by a coverage factor of $2(k=2)$, providing the $95 \%$ confidence interval. All statistical analyses were performed using linear regression analysis in JMP 10.0 (SAS Institute Inc.). The level of significance applied was 0.05 , except when stated otherwise.

\section{Results}

\subsection{Basic Composition—Dry Matter, Protein, Lipid, Carbohydrate and Ash}

The DM content of most of the studied fresh algae ranged from $18 \%$ to $43 \%$ of fresh weight (FW); the highest DM content was found in A. plicata while D. carnosa had the lowest DM content (Table 2). For all algae, protein concentrations calculated based on the total $\mathrm{N}$ (Dumas) $(14.9 \%-31.1 \%$ of DM) were $8 \%-34 \%$ higher than the crude protein concentrations obtained using the Kjeldahl method (12.3\% - 25.6\% of DM). P. rubens had the highest protein content (25.6\% of DM) according to the Kjeldahl method, while A. plicata had a higher protein content (31.1\% of DM) when using the Dumas method (Table 2). The discrepancy between the $\mathrm{N}$ concentrations obtained by the two methods ranged between $1.7 \%$ and $9.3 \%$ of DM, most likely representing intracellularly stored inorganic $\mathrm{N}$ (Table 2). The total lipid content of the nine studied algae varied only marginally from $1.0 \%$ to $1.3 \%$ of DM, with the highest lipid contents in G. vermiculophylla and P. rubens (Table 2). The carbohydrate content of the studied algae ranged between $40 \%$ and $71 \%$ (Table 2). The highest carbohydrate content was observed in P. palmata (71\% of DM) followed by G. vermiculophylla (62\% of DM), while the lowest carbohydrate content was found in $P$. rubens ( $40 \%$ of DM). Ash constituted a relatively high proportion of the DM, ranging from $12 \%$ to $30 \%$ of DM (Table 2 ).

Table 2. Dry matter (\% fresh weight), lipid, ash, carbohydrate, protein and total nitrogen content (\% dry matter) of studied red algae.

\begin{tabular}{|c|c|c|c|c|c|c|c|}
\hline \multirow[b]{2}{*}{ Algal species ${ }^{1}$} & \multirow[b]{2}{*}{ Dry matter } & \multirow[b]{2}{*}{ Lipid $^{5}$} & \multirow[b]{2}{*}{ Ash } & \multirow[b]{2}{*}{ Carbohydrate } & \multicolumn{2}{|c|}{ Protein $^{2}$} & \multirow{2}{*}{$\begin{array}{c}\text { Inorganic } \\
\text { nitrogen }\end{array}$} \\
\hline & & & & & $\begin{array}{l}\text { Kjeldahl } \\
\text { method }\end{array}$ & $\begin{array}{l}\text { Dumas } \\
\text { method }^{3}\end{array}$ & \\
\hline Ap & 42.5 & 1.1 & 13.0 & 59.1 & 23.2 & $31.1 \pm 0.8$ & 7.9 \\
\hline Gv & 18.6 & 1.3 & 19.8 & 61.9 & 13.5 & $17.8 \pm 0.6$ & 4.3 \\
\hline $\mathrm{Fl}$ & 31.0 & 1.0 & 24.0 & 55.4 & 16.0 & $20.6 \pm 0.6$ & 4.6 \\
\hline Cc & 24.0 & 1.0 & 25.1 & 53.3 & 17.1 & $26.4 \pm 1.4$ & 9.3 \\
\hline $\mathrm{Pp}$ & 29.0 & 1.2 & 11.9 & 71.0 & 12.3 & $14.9 \pm 0.2$ & 2.6 \\
\hline Ds & 22.6 & 1.2 & 22.5 & 51.2 & 21.6 & $23.4 \pm 1.0$ & 1.8 \\
\hline Dc & 18.1 & 1.2 & 22.6 & 53.0 & 19.7 & $21.5 \pm 0.7$ & 1.8 \\
\hline Od & 26.1 & n.d. ${ }^{4}$ & 30.3 & n.d. & 16.1 & $17.8 \pm 0.4$ & 1.7 \\
\hline $\mathrm{Pr}$ & 21.3 & 1.3 & 29.1 & 40.2 & 25.6 & $28.8 \pm 0.8$ & 3.2 \\
\hline $\begin{array}{c}\text { Expanded } \\
\text { uncertainty }(\%)^{6}\end{array}$ & \pm 5 & \pm 10 & \pm 4 & - & \pm 4 & - & - \\
\hline
\end{tabular}

${ }^{1}$ Letters designate algal species given in Table 1 ; ${ }^{2}$ Protein $=$ Nitrogen*6.25; ${ }^{3}$ Protein content calculated from nitrogen concentration based on the Dumas method is given as average $\pm \mathrm{SE}, \mathrm{n}=3$; ${ }^{4} \mathrm{n}$.d.: not detected due to insufficient sample volume; ${ }^{5}$ Lipid content and fatty acids composition of Odonthalia dentata (Od) was not detected due to insufficient sample volume; ${ }^{6}$ Relative expanded uncertainty of each applied method reported based on a standard uncertainty of the method multiplied by a coverage factor of $2(\mathrm{k}=2)$, providing the coverage probability of approximately $95 \%$. 


\subsection{Amino Acid Composition and Amino Acid Scores}

The total AA content of the nine red macroalgae ranged from $66 \%$ to $99 \%$ of crude protein (Table 3). The AA analyzed represented both essential and non-essential amino acids. Among the eighteen detected AAs, the macroalgae samples contained ten EAAs, namely methionine (Met), leucine (Leu), lysine (Lys), phenylalanine (Phe), tyrosine (Tyr), isoleucine (Ile), threonine (Thr), valine (Val), histidine (His), cysteine (Cys), and eight non-EAAs which were found in all analyzed species (Table 3). The non-EAAs, aspartic acid (Asp), glutamic acid (Glu), and arginine (Arg), constituted a substantial fraction of the total AAs (28\% - 40\%) in most of the nine species, while $D$. sanguinea, O. dentata, and P. rubens were also found to be rich in proline (Pro) (Table 3). In contrast, ornithine (Orn) was the non-EAA with the lowest concentration with maximum amounts of $2 \%$ of total AA in A. plicata. The ratio of EAA to non-EAA of the here studied algae was 0.7, except for F. lumbricalis, D. carnosa, D. sanguinea, where the ratio was 0.6.

The AA scores of the nine selected algae along with some animal and plant meals were calculated based on the most updated WHO/FAO/UNU AA requirement reference pattern for child school/adolescent (Figure 1) [29] [33] [34]. The first limiting AA of the six species of red algae was histidine (A. plicata, D. sanguinea, F. lumbricalis, G. vermiculophylla, P. rubens, O. dentata), while for three other species, P. palmata, C. crispus, and D. carnosa, leucine was the first limiting AA, despite the fact that Leu was the EAA present at the highest concentration in two of these species. The AA scores Lys-Met+Cys and Lys-Met+Cys-Trp-Thr were significantly higher in all of the investigated nine algae than in the chosen reference protein (Table 3).

\subsection{Fatty Acid Composition}

The fatty acid (FA) profiles of eight of the nine red algae were investigated in the present study. In total, 27 FAs were detected ranging from 12 in F. lumbricalis to all of the 27 identified FAs in $D$. sanguinea (Table 4). More than half of the lipid was made up of unsaturated fatty acid (USFA) with a $\omega 6 / \omega 3$ ratio ranging between 0.1 and 3.8. The health-beneficial Eicosapentaenoic acid (EPA; C20:5 n3) was found in all nine macroalgae ranging between $3.2 \%$ and $41.7 \%$ of total fatty acids (TFA), in G. vermiculophylla and P. palmata, respectively (Table 4). Another physiologically important long chain PUFA, Docosahexaenoic acid (DHA; C22:6 n3), was absent in four of the red algae species studied, but present in D. sanguinea, A. plicata, C. crispus and P. rubens, showing contents from $0.6 \%$ to $3.7 \%$ of TFA. The highest alpha-linoleic acid (ALA; C18:3 n3) content of 3.8\% of TFA was observed in $D$. sanguinea which is the only species in the present study that contained the Clupanodonic

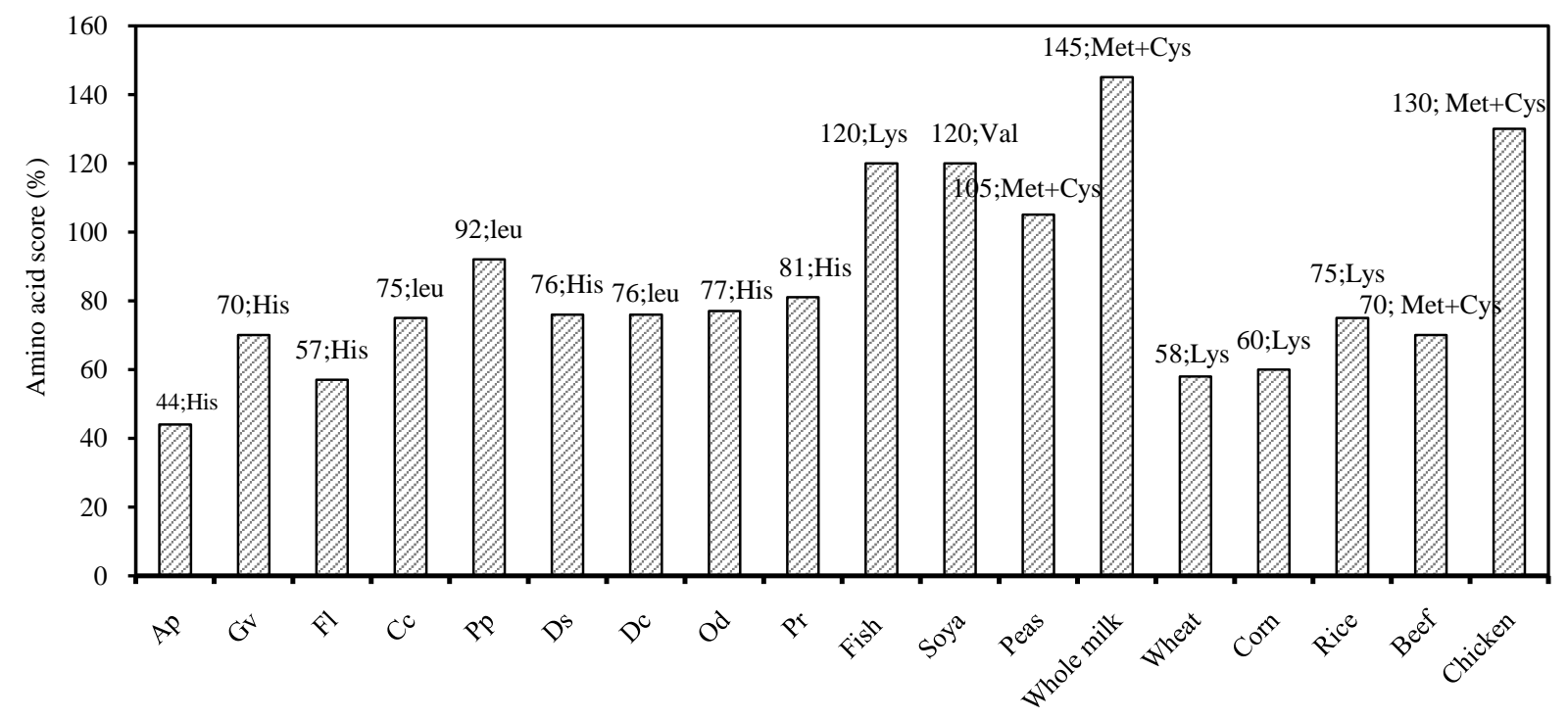

Figure 1. Amino acid score (AAS) of the first limiting Amino acid (AA) of plant and animals meals (Uhe et al., [33]; Misciattelli et al., [34]) along with the studied red algae (letters in the vertical axis designate algal species given in Table 1); The data on each column represents the AA score as well as the first limiting AA of each food resource including all the nine algae investigated; amino acid score (\%): based on FAO/WHO/UNU amino acid requirement reference pattern for school child/adolescent [29]. 
Table 3. Amino acid concentration [\% of total amino acids], amino acid scores (\%), and essential amino acid index of the studied red algae.

\begin{tabular}{|c|c|c|c|c|c|c|c|c|c|c|}
\hline \multirow{2}{*}{ Amino acids ( $\%$ total $\mathrm{AA})^{1}$} & \multicolumn{9}{|c|}{ Algal species ${ }^{2}$} & \multirow{2}{*}{$\begin{array}{c}\text { Expanded } \\
\text { uncertainty }(\%)^{3}\end{array}$} \\
\hline & Ap & Gv & $\mathrm{Fl}$ & Cc & $\mathrm{Pp}$ & Ds & Dc & Od & $\operatorname{Pr}$ & \\
\hline
\end{tabular}

EAA:

\begin{tabular}{|c|c|c|c|c|c|c|c|c|c|c|}
\hline Cystein $^{5}+$ Cystine & 3.2 & 2.4 & 3.7 & 3.4 & 3.5 & 2.4 & 2.6 & 3.0 & 2.5 & \pm 9.0 \\
\hline Histidine $^{4}$ (His) & 1.0 & 1.5 & 1.4 & 2.1 & 1.8 & 1.5 & 1.6 & 1.6 & 1.7 & \pm 13.7 \\
\hline Lysine (Lys) & 6.6 & 5.6 & 4.9 & 6.3 & 7.0 & 5.5 & 5.6 & 6.9 & 6.2 & \pm 5.3 \\
\hline Threonine (Thr) & 4.4 & 5.6 & 4.7 & 4.8 & 4.4 & 4.9 & 4.7 & 5.2 & 5.0 & \pm 5.5 \\
\hline Tyrosine $^{5}$ (Tyr) & 4.6 & 2.4 & 0.7 & 2.4 & 0.9 & 2.9 & 0.6 & 1.3 & 2.5 & \pm 10.8 \\
\hline Valine (Val) & 5.8 & 5.6 & 5.7 & 5.4 & 6.1 & 5.0 & 4.8 & 5.6 & 5.8 & \pm 6.4 \\
\hline Isoleucine (Ile) & 3.5 & 4.3 & 3.8 & 3.9 & 3.8 & 3.9 & 3.6 & 4.4 & 4.2 & \pm 8.3 \\
\hline Leucine (Leu) & 5.4 & 7.6 & 6.1 & 6.6 & 6.5 & 6.0 & 6.4 & 6.4 & 6.6 & \pm 7.4 \\
\hline Methionine (Met) & 1.4 & 2.1 & 1.4 & 1.8 & 2.1 & 1.7 & 1.6 & 1.7 & 1.8 & \pm 7.7 \\
\hline Phenylalanine (Phe) & 3.7 & 4.9 & 5.9 & 5.2 & 4.5 & 4.1 & 4.5 & 5.1 & 4.6 & \pm 5.5 \\
\hline Tryptophan (Trp) & n.d. & n.d. & n.d. & n.d. & n.d. & n.d. & n.d. & n.d. & n.d. & - \\
\hline EAA (\% total AA) & 39.6 & 41.8 & 38.3 & 41.9 & 40.3 & 37.9 & 36.2 & 41.1 & 41.0 & - \\
\hline Total EAA (mg/g protein) & 268.0 & 307.7 & 251.4 & 291.4 & 349.8 & 299.3 & 287.1 & 408.6 & 313.3 & - \\
\hline \multicolumn{11}{|l|}{ Non-EAA: } \\
\hline Arginine (Arg) & 15.4 & 8.3 & 16.2 & 9.0 & 6.1 & 6.6 & 13.5 & 6.1 & 6.9 & \pm 6.0 \\
\hline Aspartic acid (Asp) & 10.5 & 11.4 & 9.3 & 11.2 & 13.3 & 10.6 & 15.4 & 11.4 & 11.8 & \pm 5.2 \\
\hline Glutamic acid (Glu) & 9.4 & 12.4 & 10.7 & 11.7 & 16.0 & 14.4 & 10.8 & 10.4 & 11.4 & \pm 4.5 \\
\hline Serine (Ser) & 5.1 & 6.2 & 5.6 & 5.7 & 5.5 & 5.2 & 5.9 & 5.7 & 5.6 & \pm 5.8 \\
\hline Glycine (Gly) & 6.5 & 6.2 & 6.1 & 6.7 & 6.3 & 6.1 & 4.7 & 5.7 & 7.2 & \pm 6.2 \\
\hline Ornithine (Orn) & 2.0 & 1.2 & 1.6 & 1.2 & $<0.09$ & 0.1 & 0.5 & $<0.06$ & 0.1 & \pm 5.9 \\
\hline Alanine (Ala) & 5.5 & 6.9 & 5.7 & 6.7 & 7.5 & 6.3 & 7.7 & 5.9 & 7.8 & \pm 5.2 \\
\hline Proline (Pro) & 6.0 & 5.4 & 6.5 & 5.8 & 4.7 & 12.7 & 5.3 & 13.6 & 8.2 & \pm 8.4 \\
\hline Total AA (\% protein) & 67.6 & 73.6 & 65.7 & 69.5 & 86.7 & 79.0 & 79.4 & 99.4 & 76.3 & - \\
\hline EAA/non-EAA & 0.7 & 0.7 & 0.6 & 0.7 & 0.7 & 0.6 & 0.6 & 0.7 & 0.7 & - \\
\hline \multicolumn{11}{|l|}{ AA score $(\%)^{5}$} \\
\hline Lys-Met+Cys & 227 & 229 & 213 & 249 & 335 & 229 & 233 & 247 & 243 & - \\
\hline Lys-Met+Cys-Trp-Thr & 348 & 344 & 306 & 361 & 434 & 348 & 315 & 344 & 359 & - \\
\hline EAAI $^{3}$ & 90 & 100 & 85 & 100 & 100 & 100 & 91 & 100 & 100 & - \\
\hline
\end{tabular}

${ }^{1}$ Letters in parentheses are abbreviation of each AA; ${ }^{2}$ Letters designate algal species given in Table 1; AA: Amino acid; ${ }^{3}$ n.d. not detected; EAA: essential amino acid; ${ }^{4}$ Relative expanded uncertainty of each applied method reported based on a standard uncertainty of the method multiplied by a coverage factor of $2(\mathrm{k}=2)$, providing the coverage probability of approximately $95 \% ;{ }^{5}$ Essential AA for children; calculated as an essential AA: Tyrosin (can derive from Phenylalanine), Cystein (can from tyrosine and methionine); ${ }^{6} \mathrm{AA}$ score (\%): based on WHO/FAO//UNU amino acid requirement reference pattern for school child/adolescent [29]; ${ }^{7}$ EAAI: Essential amino acid index. 
Table 4. Total lipid and relative weight concentration [\%] of Total Fatty Acids in studied red algae.

\begin{tabular}{|c|c|c|c|c|c|c|c|c|c|}
\hline & \multirow{2}{*}{ Amino acids (\% total $\mathrm{AA})^{1}$} & \multicolumn{8}{|c|}{ Algal species ${ }^{2}$} \\
\hline & & Ap & Gv & $\mathrm{Fl}$ & Cc & $\mathrm{Pp}$ & Ds & Dc & $\operatorname{Pr}$ \\
\hline \multirow[t]{2}{*}{ Total lipid ${ }^{3}$} & (\% of dry matter) & 1.1 & 1.3 & 1.0 & 1.0 & 1.2 & 1.2 & 1.2 & 1.3 \\
\hline & \multicolumn{9}{|l|}{ Fatty acids composition ${ }^{2}$} \\
\hline $\mathrm{C} 12: 0$ & Lauric acid & n.d. $^{2}$ & n.d. & n.d. & n.d. & n.d. & 0.16 & 0.13 & n.d. \\
\hline $\mathrm{C} 13: 0$ & Tridecanoic acid & n.d. & n.d. & n.d. & n.d. & n.d. & 2.8 & n.d. & n.d. \\
\hline C14:0 & Myristic acid & 1.3 & 4.9 & 3.4 & 3.3 & 8.5 & 3.9 & 3.2 & 5.6 \\
\hline C14:1 n5 & Myristolenic acid & 0.2 & 1.4 & 0.5 & 0.5 & 1.3 & 0.6 & 2.3 & 0.5 \\
\hline C15:0 & Pentadecanoic acid & n.d. & 0.3 & n.d. & n.d. & n.d. & 0.3 & 0.3 & 0.4 \\
\hline C16:0 & Palmitic acid & 16.9 & 21.6 & 44.4 & 36.1 & 29.0 & 28.1 & 26.2 & 26.8 \\
\hline C16:1 n7 & Palmitol acid & 1.5 & 0.7 & 4.0 & 3.2 & n.d. & 5.4 & 1.7 & 6.4 \\
\hline $\mathrm{C} 17: 0$ & Margaric acid & n.d. & n.d. & n.d. & n.d. & n.d. & 0.3 & n.d. & 0.3 \\
\hline C17:1 n7 & Heptadecenoic acid & 0.8 & 0.5 & 1.4 & 1.7 & 1.3 & 1.8 & n.d. & 3.4 \\
\hline C18:0 & Stearic acid & 1.8 & 3.4 & 1.9 & 1.6 & 1.6 & 2.3 & 0.7 & 2.6 \\
\hline C18:1 n9 & Oleic acid & 19.2 & 16.2 & 16.4 & 12.2 & 3.6 & 7.5 & 6.5 & 7.6 \\
\hline C18:1 n7 & cis-vaccen acid & 2.3 & 0.6 & 1.7 & 1.9 & 1.6 & 2.4 & 0.9 & 2.3 \\
\hline C18:2 n6 & Linoleic acid & 2.0 & 7.4 & 1.0 & 1.8 & 1.0 & 2.0 & 1.5 & 1.6 \\
\hline C18:3 n6 & Gamma-linolenic acid (GLA) & 0.6 & 0.6 & n.d. & 0.5 & n.d. & 0.2 & n.d. & n.d. \\
\hline C18:3 n3 & alpha-linoleic acid (ALA) & 0.6 & 2.8 & 0.2 & 1.2 & 0.6 & 3.8 & n.d. & 1.2 \\
\hline C18:4 n3 & Stearidonic acid (SDA) & n.d. & 1.8 & n.d. & 0.5 & 0.8 & 1.0 & n.d. & 1.9 \\
\hline $\mathrm{C} 20: 0$ & Arachidic acid & n.d. & n.d. & n.d. & n.d. & n.d. & 0.1 & n.d. & 0.2 \\
\hline C20:1 n11 & Gadolenic acid & n.d. & n.d. & n.d. & n.d. & n.d. & 0.3 & n.d. & 0.7 \\
\hline C20:1 n9 & Eicosenoic acid & n.d. & n.d. & n.d. & n.d. & n.d. & 0.5 & n.d. & 0.9 \\
\hline $\mathrm{C} 20: 2 \mathrm{n} 6$ & Eicosadienoic acid & n.d. & n.d. & n.d. & n.d. & n.d. & 0.3 & n.d. & 0.3 \\
\hline C20:3 n6 & Dihomo-gamma-linolenic acid (DGLA) & 3.7 & 2.1 & n.d. & n.d. & n.d. & 0.2 & n.d. & 0.3 \\
\hline C20:4 n6 & Arachidonic acid (AA) & 28.2 & 18.9 & 10.2 & 15.5 & 3.3 & 4.7 & 17.0 & 13.2 \\
\hline C20:5 n3 & Eicosapentaenoic acid (EPA) & 12.2 & 3.2 & 8.7 & 11.6 & 41.7 & 4.2 & 13.4 & 6.2 \\
\hline C22:0 & Behenic acid & 1.2 & n.d. & n.d. & 0.1 & 2.6 & 0.4 & 4.6 & n.d. \\
\hline C22:1 n9 & Erucic acid & n.d. & n.d. & n.d. & n.d. & n.d. & 0.3 & n.d. & n.d. \\
\hline $\mathrm{C} 22: 5$ n3 & Clupanodonic acid (DPA) & n.d. & n.d. & n.d. & n.d. & n.d. & 0.3 & n.d. & n.d. \\
\hline \multirow[t]{6}{*}{ C22:6 n3 } & Docosahexaenoic acid (DHA) & 1.1 & n.d. & n.d. & 0.62 & n.d. & 2.0 & n.d. & 3.7 \\
\hline & Not identified fatty acids & 6.5 & 13.8 & 6.3 & 7.7 & 3.2 & 24.0 & 21.7 & 14.0 \\
\hline & $\omega 3$ & 13.9 & 7.7 & 9.0 & 13.9 & 43.0 & 11.4 & 13.5 & 13.0 \\
\hline & $\omega 6$ & 34.5 & 29.0 & 11.2 & 17.8 & 4.3 & 7.4 & 18.5 & 15.3 \\
\hline & $\omega 9$ & 19.2 & 16.2 & 16.4 & 12.2 & 3.6 & 8.3 & 6.5 & 8.5 \\
\hline & $\omega 6 / \omega 3$ & 2.5 & 3.8 & 1.3 & 1.3 & 0.1 & 0.7 & 1.4 & 1.2 \\
\hline
\end{tabular}

${ }^{1}$ Letters designate algal species given in Table $1 ;{ }^{2}$ n.d. not detected; ${ }^{3}$ Lipid content and fatty acids composition of Odonthalia dentata (Od) was not detected due to insufficient sample volume; Relative Expanded uncertainty of each applied method reported based on a standard uncertainty of the method multiplied by a coverage factor of $2(\mathrm{k}=2)$, providing the coverage probability of approximately $95 \%$; Lipid: $\pm 10 \%$, and for individual FA: $\pm 10 \%$. 
acid fatty acid (DPA; $0.3 \%$ of TFA). The arachidonic acid (AA; C20:4 n6) content varied from 4.7\% to 28.2\% of TFA.

Most of the examined species had approximately $90 \%$ of TFA as long chain FA (C15-C22). In contrast, the content of shorter chain FAs with C12-C14 carbon were generally low and varied between 1.5\% of TFA in $A$. plicata to $9.9 \%$ of TFA in P. palmata. The FA composition of the herein analyzed macroalgae consisted of $21.2 \%$ 49.6\% saturated fatty acids (SFA), $7.8 \%$ - 23.9\% of monounsaturated fatty acids (MUFA), and $18.8 \%-48.3 \%$ of PUFA (Figure 2). Except for F. lumbricalis, D. sanguinea and D. carnosa, it was found that unsaturated fatty acids contributed more than half of all the identified FA.

As represented in Table 4, the proportion of n-9-FA varied between $3.6 \%$ and $19.2 \%$ of TFAs in P. palmata and A. plicata, respectively. Furthermore, the studied red algae contained small amounts of n-7 as well as n-11 FAs.

\subsection{Carotenoid Composition}

All species contained $\beta$-carotene while lutein was not detected in G. vermiculophylla and zeaxanthin was not detected in F. lumbricalis, P. palmata, and D. carnosa (Figure 3).

The highest lutein content was found in $P$. rubens and $F$. lumbricalis with amounts of 15.2 and $13.3 \mathrm{mg} \cdot \mathrm{kg}^{-1}$ of DM, respectively, while only $1.4 \mathrm{mg} \cdot \mathrm{kg}^{-1}$ was present in dry matter of $O$. dentata. Among the studied species, G. vermiculophylla was particularly rich in zeaxanthin; the concentration of this carotenoid was $9.3 \mathrm{mg} \cdot \mathrm{kg}^{-1} \mathrm{of}$ DM. Although zeaxanthin has been reported to be one of the common xanthophylls in red algae, it was not identified in several of the here studied red algae (F. lumbricalis, P. palmaria, and D. carnosa), while in the other species, the concentration was low, $0.9-4 \mathrm{mg} \cdot \mathrm{kg}^{-1}$ of algal DM. Regarding $\beta$-carotene, $P$. rubens had the highest content (15.7 mg. $\mathrm{kg}^{-1}$ of DM), almost $45 \%$ more than $G$. vermiculophylla and $F$. lumbricalis, whereas $P$. palmata had the lowest content (1.9 $\mathrm{mg} \cdot \mathrm{kg}^{-1}$ of DM) followed by O. dentata and A. plicata (Figure 3).

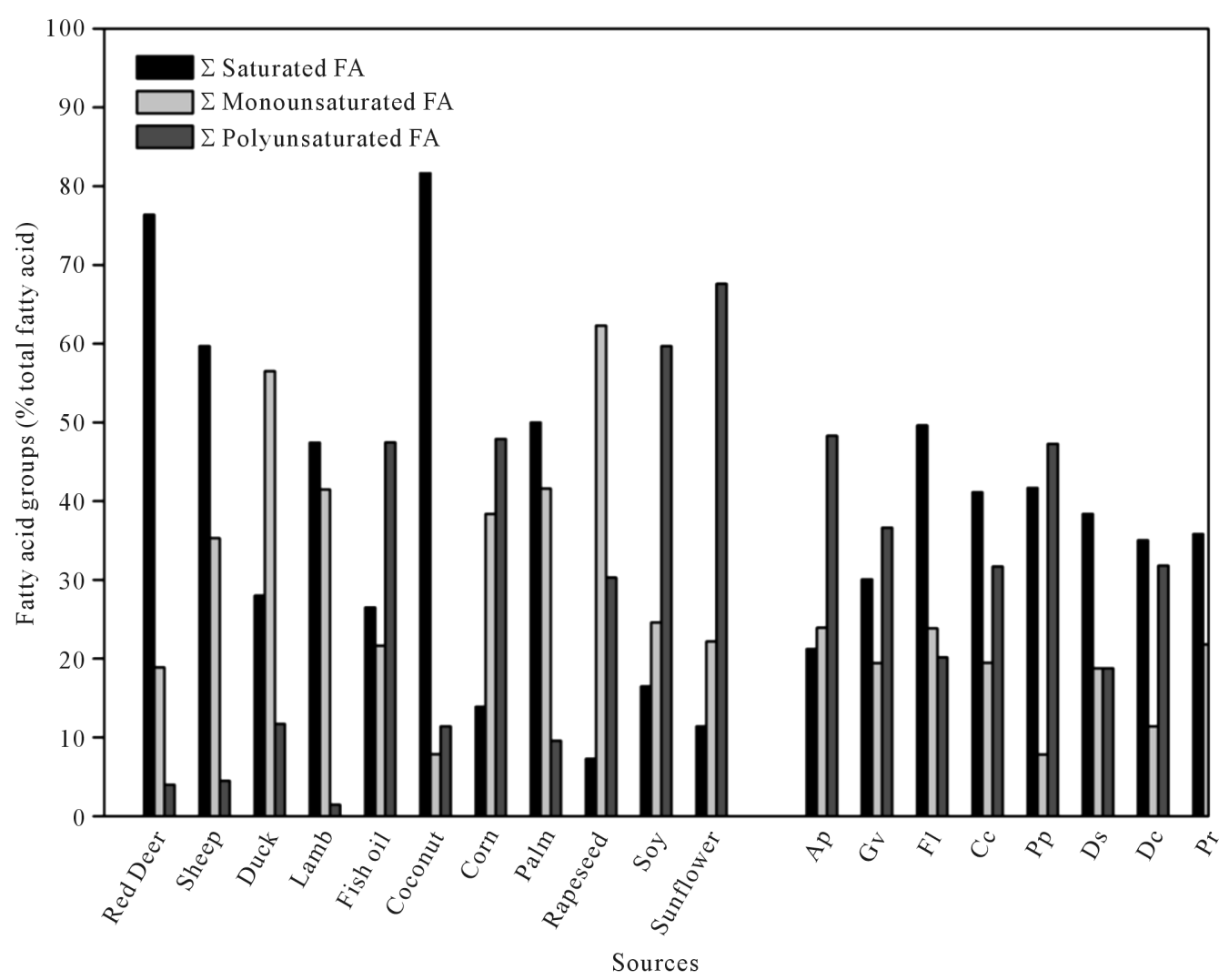

Figure 2. Identified saturated, monounsaturated, and polyunsaturated fatty acids (\% of total fatty acid) of animal fats (Lísa et al. [131]; Landim et al. [132]; Dillon et al. [63]), vegetable oils (Hoekman et al. [133]) and the studied red algae (letters in the vertical axis designate algal species given in Table 1). 


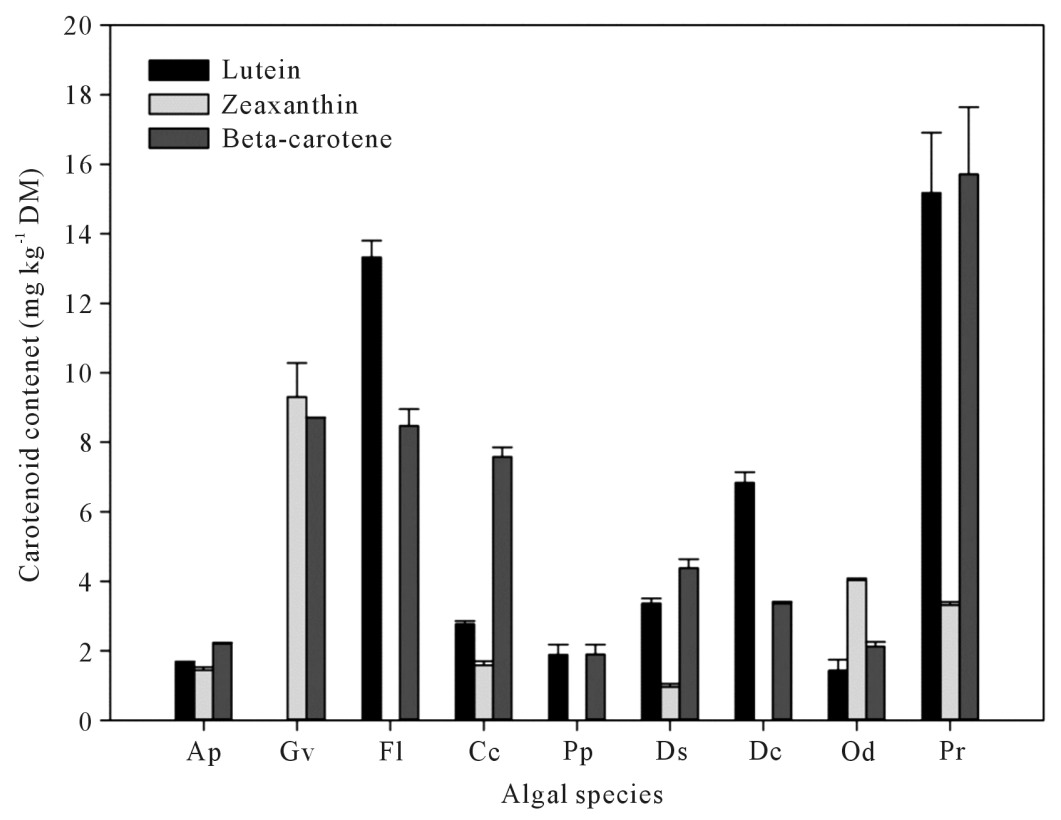

Figure 3. Carotenoid concentration (mg. $\mathrm{kg}^{-1}$ of dry matter (DM)) of the studied red algae (letters in the vertical axis designate algal species given in Table 1.

\subsection{Macro minerals, Trace Elements and Toxic Metals}

All nine red algae contained high concentrations of essential macro minerals and trace elements (Table 5). $P$. rubens had the highest concentration of $\mathrm{Fe}, \mathrm{Mg}$, Se, manganese (Mn), chromium (Cr) and molybdenum (Mo) of the nine algae. C. crispus had the highest concentrations of Ca and P. D. carnosa had the highest concentrations of $\mathrm{Na}$ and $\mathrm{Zn}$, whereas the highest concentrations of $\mathrm{K}$ and $\mathrm{Cu}$, were found in G. vermiculophylla and in $D$. sanguinea, respectively. Regarding the macronutrients, the $\mathrm{N}$ concentration ranged from $2.4 \%$ of DM in $P$. palmata to $4.9 \%$ in A. plicata, the P contents from $0.1 \%$ of DM in F. lumbricalis to $0.3 \%$ in C. crispus, and finally $\mathrm{K}$ from $1.3 \%$ of DM in D. carnosa to $4.9 \%$ in G. vermiculophylla (Table 5). Thus, not one species had the highest content of all three macronutrients. Three species contained more $\mathrm{K}$ than $\mathrm{N}$ : G. vermiculophylla, $P$. palmata and $F$. lumbricalis.

The Na contents of all the here studied algae were between 12 to 125 times below the Na content in table salt, and except for in $D$. carnosa, the $\mathrm{Na} / \mathrm{K}$ ratios were below 1.0 in all the red algae studied (0.08 - 0.94), lowest in $P$. palmata. Other potentially important minerals for salt replacement blends, i.e. Ca and $\mathrm{Zn}$, were also present in relatively high amounts (2.7 - 54 g Ca $\mathrm{kg} \mathrm{DM}^{-1}$ and 16 - $112 \mathrm{mg} \mathrm{Zn} \mathrm{kg} \mathrm{DM}{ }^{-1}$, respectively) (Table 5).

C. crispus contained the highest concentrations of cadmium $(\mathrm{Cd})$ and lead $(\mathrm{Pb})$ followed by P. rubens, as compared to the other species here investigated (Figure 4(a) and Figure 4(b)). Regarding total As, C. crispus, D. carnosa and A. plicata contained approximately twice as high concentrations as the remaining six species (Figure 4(c)). There were no significant correlations between the tissue content of lipids or $\mathrm{N}$ (crude protein) in the nine red algae and any of the toxic metals.

Generally, carbohydrate content was inversely correlated to the contents of crude protein and ash ( $\mathrm{P}=0.029$ and 0.002, respectively), and also to the contents of $\mathrm{Mg}, \mathrm{Cr}$ and $\mathrm{Pb}(\mathrm{P}=0.024,0.047$ and 0.032 , respectively). The ash concentrations were positively correlated to the concentrations of $\mathrm{Mg}, \mathrm{Mo}, \mathrm{S}$ and $\mathrm{Pb}(\mathrm{P}=0.031,0.034$, 0.013 and 0.049 , respectively). The concentration of $\mathrm{K}$ was positively correlated to the carbohydrate content ( $\mathrm{P}$ $=0.036)$, and inverse correlated to the content of $\mathrm{N}$ (crude protein) $(\mathrm{P}=0.002)$.

\section{Discussion}

\subsection{Protein and Amino Acids}

The protein content of both of the benchmark species, P. palmata and C. crispus, were lower than described from other studies [7] [9] [35] with most typical values being around 20\% [36]. However, the variation seems 
Table 5. Content of dry matter (DM), total ash, minerals and essential trace metals for human nutrition of the studied red algae. Contents of DM are given as \% of fresh weight (FW), the contents of total minerals (ash), carbon, nitrogen and sulphur are given as \% of DM, remaining minerals and trace metals are given as $\mathrm{mg} 100 \mathrm{~g} \mathrm{DM}^{-1}$ (with the exception of selenium (Se) and molybdenum (Mo) where concentrations are given as $\mu \mathrm{g} 100 \mathrm{~g} \mathrm{DM}^{-1}$ ), and finally, the $\mathrm{Na} / \mathrm{K}$ ratio of dry matter of the studied red algae as well as the recommended daily intake for adults (RDI) are given in $\mathrm{mg} \mathrm{day}^{-1}$ of minerals and trace metals. The highest concentrations of any specific mineral found among the nine macroalgae are marked in bold. Values are given as average $\pm \mathrm{SE}, \mathrm{n}=3$. Concentrations of minerals in vegetables/fruits as well as terrestrial and aquatic animals are given as $\mathrm{mg} 100 \mathrm{~g}_{\text {fresh weight }}{ }^{-1}$, again with the exception of selenium (Se) and molybdenum (Mo) where concentrations are given as $\mu \mathrm{g} 100 \mathrm{~g}_{\text {fresh weight }}{ }^{-1}$.

\begin{tabular}{|c|c|c|c|c|c|c|c|c|c|c|c|c|}
\hline & \multirow{2}{*}{$\mathrm{RDI}^{2}$} & \multicolumn{9}{|c|}{ Algal species ${ }^{1}$} & \multirow{2}{*}{$\begin{array}{l}\text { Vegetables } \\
\text { and fruits }\end{array}$} & \multirow{2}{*}{$\begin{array}{c}\text { Terrestrial } \\
\text { \& aquatic } \\
\text { animals }^{4}\end{array}$} \\
\hline & & $A p$ & $G v$ & $\mathrm{Fl}$ & $C c$ & $P p$ & Ds & $D c$ & Od & $\mathrm{Pr}$ & & \\
\hline $\begin{array}{l}\text { Dry matter } \\
\text { content } \\
(\% \text { of } F W)\end{array}$ & & 42.5 & 18.6 & 31.0 & 24.0 & 29.0 & 22.6 & 18.1 & 26.1 & 21.6 & & \\
\hline $\begin{array}{l}\text { Total mineral } \\
\text { content } \\
\text { (\% of DM) }\end{array}$ & & 13.0 & 19.8 & 24.0 & 25.1 & 11.9 & 22.5 & 22.6 & 30.3 & 29.1 & & \\
\hline \multicolumn{13}{|l|}{$\begin{array}{l}\text { Macro } \\
\text { minerals } \\
\text { (\% of DM) }\end{array}$} \\
\hline Carbon (C) & & $38.6 \pm 0.4$ & $34.7 \pm 0.8$ & $32 \pm 2$ & $29.5 \pm 0.6$ & $38.1 \pm 0.8$ & $34.2 \pm 0.5$ & $34.7 \pm 0.2$ & $38.5 \pm 0.7$ & $32 \pm 1$ & & \\
\hline Nitrogen (N) & & $5.0 \pm 0.1$ & $2.8 \pm 0.1$ & $3.3 \pm 0.1$ & $4.2 \pm 0.2$ & $2.4 \pm 0.1$ & $3.8 \pm 0.2$ & $3.4 \pm 0.1$ & $2.9 \pm 0.1$ & $4.6 \pm 0.1$ & & \\
\hline Sulphur (S) & & $1.4 \pm 0.1$ & $3.1 \pm 0.2$ & $4.0 \pm 0.3$ & $6.2 \pm 0.8$ & $0.6 \pm 0.1$ & $3.6 \pm 0.1$ & $2.9 \pm 0.1$ & $2.5 \pm 0.1$ & $4.5 \pm 0.1$ & & \\
\hline \multicolumn{13}{|l|}{$\begin{array}{l}\text { Minerals/trace } \\
\text { metals }^{5} \text { (mg } 100 \mathrm{~g} \\
\mathrm{DM}^{-1} \text { ) }\end{array}$} \\
\hline Sodium (Na) & & $613 \pm 24$ & $1017 \pm 67$ & $1889 \pm 69$ & $3059 \pm 263$ & $319 \pm 21$ & $1261 \pm 551$ & $3311 \pm 291$ & $824 \pm 55$ & $837 \pm 82$ & $0.04-227$ & $74-394$ \\
\hline Potassium (K) & 2000 & $2001 \pm 163$ & $4912 \pm 224$ & $3478 \pm 243$ & $3256 \pm 307$ & $4111 \pm 246$ & $1939 \pm 60$ & $1304 \pm 57$ & $2659 \pm 114$ & $1363 \pm 59$ & $20-730$ & $219-368$ \\
\hline Calcium (Ca) & 800 & $1151 \pm 220$ & $401 \pm 106$ & $1347 \pm 284$ & $5398 \pm 335$ & $933 \pm 118$ & $1730 \pm 178$ & $267 \pm 19$ & $1382 \pm 278$ & $4573 \pm 1025$ & $58.7-600$ & $14-68$ \\
\hline Iron (Fe) & 14 & $27.3 \pm 8.8$ & $35.2 \pm 1.8$ & $46.9 \pm 2.8$ & $48.8 \pm 15.6$ & $30.7 \pm 2.4$ & $71.3 \pm 9.1$ & $10.8 \pm 0.4$ & $67.6 \pm 3.0$ & $80.1 \pm 12.1$ & $0.13-3.01$ & $0.4-3.72$ \\
\hline Phosphorus (P) & 700 & $246 \pm 13$ & $109 \pm 8$ & $84 \pm 7$ & $289 \pm 26$ & $272 \pm 18$ & $128 \pm 5$ & $\begin{array}{ll}157 & 10\end{array}$ & $105 \pm 3$ & $204 \pm 9$ & 16.2 - 437 & $176-231$ \\
\hline Magnesium (Mg) & 375 & $346 \pm 18$ & $314 \pm 20$ & $663 \pm 60$ & $930 \pm 81$ & $160 \pm 12$ & $370 \pm 11$ & $424 \pm 35$ & $342 \pm 11$ & $1265 \pm 51$ & $5.5-191$ & $20-35$ \\
\hline Zink (Zn) & 10 & $1.8 \pm 0.2$ & $2.4 \pm 0.8$ & $1.6 \pm 0.1$ & $7.4 \pm 0.5$ & $2.1 \pm 0.1$ & $4.9 \pm 0.1$ & $11.2 \pm 1.5$ & $2.8 \pm 0.2$ & $6.0 \pm 0.4$ & $0.05-11.8$ & $0.61-11$ \\
\hline Selenium $(\mathrm{Se})^{6}$ & 55 & $17 \pm 0$ & n.d. & n.d. & $61 \pm 25$ & n.d. & $34 \pm 7$ & n.d. & $30 \pm 3$ & $62 \pm 5$ & $0.1-60$ & $24-43$ \\
\hline Copper (Cu) & 1 & $0.41 \pm 0.03$ & $0.15 \pm 0.0$ & $0.33 \pm 0.04$ & $0.51 \pm 0.06$ & $0.47 \pm 0.03$ & $1.20 \pm 0.05$ & $0.49 \pm 0.02$ & $0.81 \pm 0.06$ & $0.93 \pm 0.06$ & $0.004-0.24$ & $0.06-0.92$ \\
\hline Manganese (Mn) & 2 & $17.7 \pm 2.5$ & $50.2 \pm 1.2$ & $76.4 \pm 16.7$ & $65.3 \pm 12.6$ & $57.8 \pm 4.2$ & $86.2 \pm 150$ & $0.50 \pm 0.0$ & $47.9 \pm 4.2$ & $139.2 \pm 18.4$ & $0.01-0.66$ & $0.01-0.56$ \\
\hline Chrome (Cr) & 0.040 & $0.11 \pm 0.02$ & $0.05 \pm 0.01$ & $0.07 \pm 0.03$ & $0.11 \pm 0.03$ & $0.07 \pm 0.01$ & $0.11 \pm 0.01$ & $0.03 \pm 0.0$ & $0.12 \pm 0.0$ & $0.20 \pm 0.02$ & $<0.018$ & - \\
\hline $\begin{array}{l}\text { Molybdenum } \\
(\mathrm{Mo})^{6}\end{array}$ & 50 & $18 \pm 2$ & $24 \pm 1$ & $53 \pm 11$ & $66 \pm 16$ & $58 \pm 11$ & $48 \pm 6$ & $60 \pm 1$ & $79 \pm 8$ & $102 \pm 15$ & $0.001-150$ & - \\
\hline $\mathrm{Na} / \mathrm{K}$ ratio & & 0.31 & 0.21 & 0.54 & 0.94 & 0.08 & 0.65 & 2.54 & 0.31 & 0.61 & & \\
\hline
\end{tabular}

${ }^{1}$ Letters designate algal species given in Table 1 ; ${ }^{2}$ Sundhedsministeriet [97]; ${ }^{3}$ Martínez-Ballesta [92]; ${ }^{4}$ Tacon [14]; ${ }^{5}$ Letters in parentheses are the elemental symbols of each mineral; ${ }^{6}$ Concentrations of selenium and molybdenum are given in $\mu \mathrm{g} 100 \mathrm{~g} \mathrm{DM}^{-1}$ for the algae and $\mu \mathrm{g} 100 \mathrm{~g}$ for fruits/vegetables and animals; n.d. not detected. 

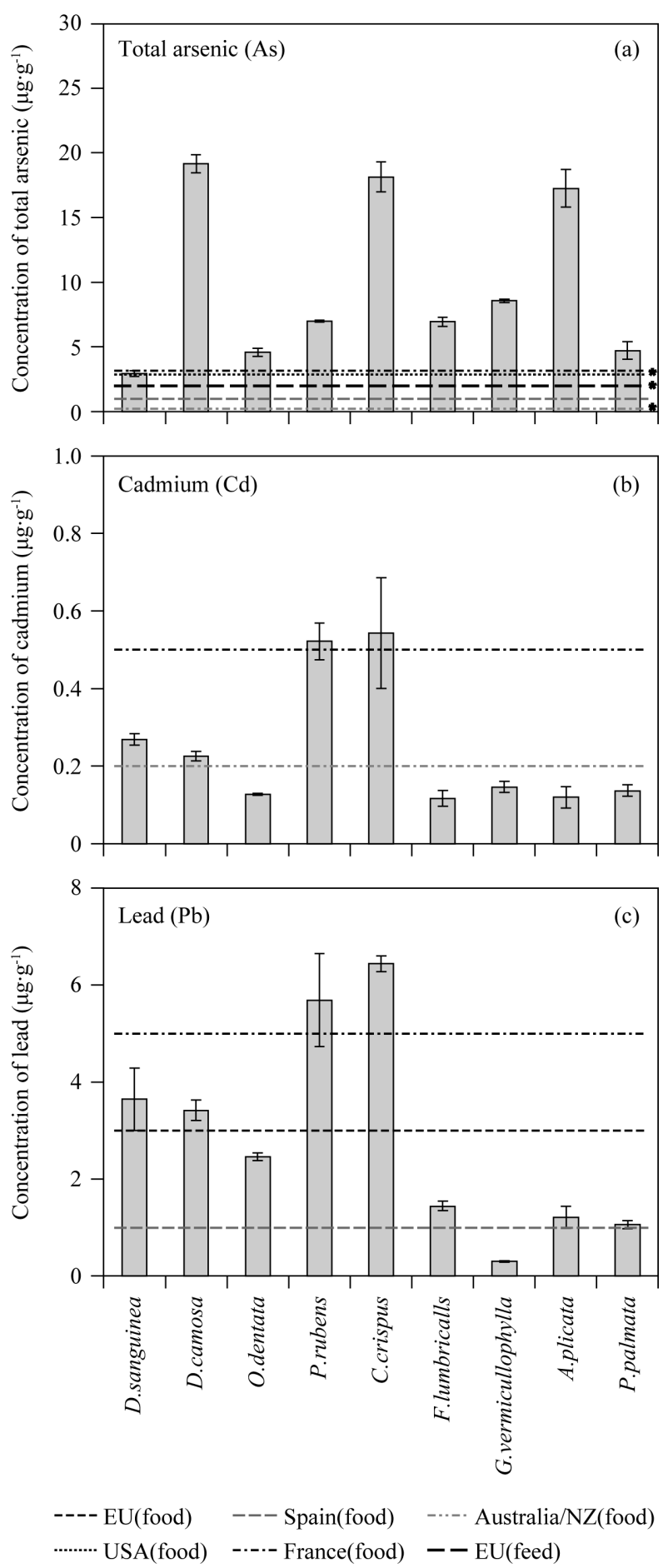

Figure 4. Concentrations of critical heavy metals in the dry tissue of the nine red algae, in relation to relevant limit values for use in food, feed and soil improvement ( $\mu \mathrm{g}$ $\mathrm{g} \mathrm{DM}^{-1}$ (ppm)). (a) Total arsenic; (b) Cadmium; (c) Lead. Values represent average \pm SE $(n=3)$. Solid horizontal lines indicate limit values of the three metals in food, feed and sludge for soil improvement as given by legal authorities in Spain, France, EU, USA, Denmark and Australia/New Zealand. Lines marked with * refer to limit values for inorganic arsenic. The values derive from Almela et al. [101]: Spain (food), USA (food, inorganic As), France (food), Australia/New Zealand (food). EU [100]: EU (feed). Holdt and Kraan [2]: EU (food), USA (food, Pb). 
well within the range to be expected based on geographical and seasonal differences [37] [38]. For instance, investigation on seasonal variation of protein content from $P$. palmata revealed the highest content during the winter-spring period ( $22 \%$ of DM), while it turned out to be nearly half of this during the summer-autumn period (12\% of DM) [7]. The relatively low content of protein in the algae as compared to other studies can be explained by the same reasons as those causing the high content of carbohydrates: the low availability of nutrients and high insolation in summer in Danish inner waters.

Generally, the total AA content of each macroalgae was lower than its crude protein content (Table 3). In this study, the total AA concentration ranged from $66 \%$ to $99 \%$ of crude protein which implied low amounts of the organic non-protein nitrogenous materials, such as free amino acids and chlorophylls, in these algae. A. plicata, $P$. palmata, and $O$. dentata stand out as having a high amount of Lys which is comparable with the Lys content in soya and egg (6.1\% and 7\% TAA, respectively) [7]. Because of the nutritional value of Lys, this AA has received much attention as the most likely limiting AA in cereal proteins. Lys is increasingly used as an AA additive in animal feed particularly for poultry and pigs, to obtain a well-balanced protein feed with minimal surplus of nitrogen. Leu was the major component of EAAs in the remaining six species investigated in the present study.

Evidence about human and animal diet shows that stimulation of muscle protein synthesis would be optimized with sufficiently high dosage of Leu ( $2.5 \mathrm{~g}$ at each of three meals day $\left.{ }^{-1}\right)$ in the presence of adequate dietary energy [39]. The AA of most of the species were on the other hand characterized as being deficient in His followed by Tyr and Met (Table 3), which is in accordance with data reported by Galland-Irmouli et al. [7] and Mouritsen et al. [36] for P. palmata. It is noteworthy that although the Met content of the nine selected algae was among the three EAAs of the lowest concentrations, the Met content of the red algae proteins is still comparable with the Met content of plant-derived proteins, especially those derived from legumes or nuts, which range from $0.85 \%$ to $2.3 \%$ of the protein [40].

The large content of non-EAA, in particular Glu and Asp, potentially provide the macroalgae with a strong umami flavor [41], making them attractive components for flavoring food as well as components with a number of possible effects in relation to nutrition and health e.g. appetite stimulation in elderly individuals or other dietetic purposes. In addition, as listed in Table 3, the nine red macroalgae also contain the sweet flavor proline (Pro), serine (Ser), and alanine (Ala) as well as bitter AA, such as Ile and Val, which enrich the algae species with a complex taste [41] [42].

In this study, the AA scores of the red algae were relatively high and ranged from $44 \%$ to $92 \%$. Although $A$. plicata contained the highest protein content after $P$. rubens (Figure 1), it demonstrated the lowest AA score. Moreover, some of the studied algal species such as P. rubens, P. palmata, and O. dentata obtained a considerably higher AA score than is typically found in vegetable and/or animal meals [43] [44]; this suggests that these marine photosynthetic organisms can be a valuable source of AA. On the other hand, the algal AA scores did not exceed the scores of high quality protein sources such as milk, soya, and fish meal. The AA scores Lys-Met+Cys and Lys-Met+Cys-Trp-Thr are high in all the investigated algae (Table 3). Since the first limiting AA for adults in nearly all foods (e.g. legumes) is generally Met+Cys, and in cereal grains Lys (Figure 1), the AA contents of the given algae could be considered complementary to these plant proteins, calling attention to the potentials of mixed proteins. Apart from Lys and Met+Cys, two sulphur containing AA, Trp and Thr, have generally been reported to be present at a low level in the protein consumed in a typical human diet [45]. Therefore, despite that Trp was not analyzed in the nine red algae, the high content of the Lys-Met+Cys-Trp-Thr score indicated a well-balanced protein quality. Moreover, all the red algae studied had high amount of EAAI (Table 3). All algae showed the maximum score of 100 , with the exception of A. plicata, F. lumbricalis, and D. carnosa, which showed EAAI scores between 85 and 91.

In the light of the decline in the world fish population as well as the drawbacks associated with plant-derived proteins, the use of selected algae analyzed in this work in the development of nutritive supplementary diet for human and animal feed may be applicable [14] [46].

Different methods have been discussed to estimate the average protein requirement for the human body [47]. Based on the analysis of available nitrogen balance studies, the average daily intake of protein to meet the body need is approximately $0.8 \mathrm{~g}$ of good quality protein $\mathrm{kg}^{-1}$ body weight of men and women. Regarding livestock animals such as pigs, turkeys, and broilers approximately 165, 260, and $210 \mathrm{~g}$ of crude protein per kg of dry feed is required in their growing life stage, respectively [48]. Moreover, fish diets typically contain between $20 \%$ and $55 \%$ crude protein depending on the fish species [49]. Sources of plant and/or animal-derived proteins for hu- 
mans and animals (e.g. as functional food and fish feed) are various: corn (9.4 g/100g of DM), wheat (10.7 $\mathrm{g} / 100 \mathrm{~g}$ of DM), peas (2.8 g/100g of DM), almond (21.15 g/100g of DM), soybean (36.4 g/100g of DM), salmon (22.6 g/100g of DM) [50]. Fishmeal usually contains $65 \%$ of crude protein, but the protein content can vary from $57 \%$ to $77 \%$, depending on the species of fish processed into fishmeal [51]. However, recent decline in availability of commercial aquaculture feed as well as difficulties in plant cultivation limited some applications in the food and feed trade. On the other hand, significant increases in global demand for livestock products will require increasing amounts of feed protein supplies and alternatives sources will need to be continually reviewed. With respect to the relatively low crude protein content of the studied macroalgae, they seem more potent as alternative plant protein supplement sources for humans and animals than as a stable food source such as chicken or peas. As a mixed protein source they can also improve the nutritional quality.

With respect to the human diet, the recent AA requirement pattern [29] reported the total EAA content for schoolchild/adolescent of $291 \mathrm{mg} \cdot \mathrm{g}^{-1}$ protein [52]. As shown in Table 3, total EAA content varied from 251 to nearly $409 \mathrm{mg} \cdot \mathrm{g}^{-1}$ protein. Consequently with respect to the reference pattern, all the algae studied seemed to be able to contribute adequate levels of total EAA either individually or mixed in an appropriate portion with each other (Figure 1). However, the nutritional values of macroalgae obtained here are based on chemical analysis only. Hence, biological evaluation using human and animal diet studies would be required to establish the actual nutritional value of these macroalgae.

In general, marine macroalgae could be a potential source for human and particularly animal nutrition such as pig, chicken, oyster, salmon or trout, all of great commercial interest [49]. AAs are by far the largest feed additive group and their market segment is expected to reach $\$ 18.8$ billion by 2017, up from $\$ 9.6$ billion in 2010 [53].

For promoting growth and health of fish, the content of EAA is one of the principal factors in dietary nutrition and the proportion of each EAA in formulated feed can change based on different factors such as species variety [49] [54] [55]. Hence, the presented nine red algae species could be useful in developing nutrient-balanced, cost-effective research diets, and practical feeds for different cultivated fish.

Results like those obtained from this study, are needed in order to determine how to blend different algae species in various proportions to achieve the required level of AA in the formulated diet for specific human age groups and/or the candidate species proposed to be cultivated. However, although the use of the studied algal proteins in animal and human diets seems to be a promising way for utilizing these under-exploited marine resources, the digestibility of algal protein should be investigated in the future. Few investigated the in vivo digestibility of macroalgae proteins and available studies about their assimilation by human have not provided conclusive results. The protein digestibility seems to be limited by the algal non-protein fraction (i.e. phenolic compounds and polysaccharides) and high rate of red macroalgae protein degradation in vitro have been reported when using digestive proteolytic enzymes (i.e. pepsin, pancreatin, and pronase) [11]. As the red algae generally possess low levels of phenols and high protein content [56], the probability of high digestibility in the studied red algae could though be expected.

\subsection{Lipids and Fatty Acids}

The total lipid content of the present macroalgae was low (Table 2). These results are lower than lipid contents reported for both of the "bench mark species" in the literature: P. palmata 3.8\% of DM [9] and C. crispus 3\% of DM [57], but similar to those determined by Kumari et al. [58] for A. plicata (1.4\% of DM). The variations in lipid content in different macroalgae were attributed either to the species, seasonal variation or environmental factors or a combination. Generally, the lipid content of seaweeds is low, less than 5\% [2]. The ACA content of A. plicata in the present study (28.2\% TFA) was lower than that reported by Kumari et al. [58] for the same species from Kotuda, Japan (34.1\% of TFA), while the herein reported content of $15.5 \%$ in C. crispus is in agreement with values reported by Fleurence et al. [59] and van Ginneken et al. [60].

In general, it should be mentioned that the FA composition of the examined algae demonstrated the pattern distinct for the red algae with relatively higher levels of palmitic acid (C16:0), oleic acid (C18:1 n9), ACA and EPA. These fatty acids together accounted for $44.5 \%$ - 79.6\% of TFA, whereas C18 PUFAs were present as minor components only, with ranges between $1.3 \%$ of TFA in F. lumbricalis to $12.5 \%$ of TFA in G. vermiculophylla. The present findings are therefore in accordance with data reported by Kumari et al. [58], in which among 13 red algae, 12 of them had a low content of C18 PUFA. Comparison of the SFA and USFA contents of 
A. plicata, C. crispus and P. palmata determined in the present study were relatively similar to those reported in the literature for the same species [58] [61] [62]. Among the unsaturated fatty acids, the content of MUFAs in almost all of the species was lower than the content of PUFAs. However, palmitoleic acid (C16:1 n7) and oleic acid were the predominant MUFAs and varied between 3.6\% of TFA in P. palmata to 20.6\% of TFA in A. plicata.

Most of the here studied red algae species such as A. plicata, P. palmata, G. vermiculophylla, and C. crispus contain approximately the same level of PUFAs as is seen in fish oil and considerably higher level of PUFAs than is typically found in vegetable oils and animal fats. The $\omega 6 / \omega 3$ ratios were ranging between 0.1 and 3.8 which is also comparable with $\omega 6 / \omega 3$ of fish oil (approximately 0.2) (Table 4) [63]. P. palmata had the lowest $\omega 6 / \omega 3$ ratio due to its high content of EPA. This suggests that these marine photosynthetic organisms can be a source of dietary PUFAs (Figure 2), thus making use of these seaweeds for consumption or as a functional food or feed ingredient may contribute significantly and be an improvement of the dietary supply of the same quality as fish oil.

\subsection{Carbohydrate}

The P. palmata carbohydrate content (71\% of DM) found in this study is in the high end of the range reported for this species in other studies (38\% - 74\% of DM) [2] [64]. The carbohydrates of Palmariales are described as water soluble xylans, most likely storage compounds, but with a potential role in structural components [23], and there is no present commercial exploitation of carbohydrates from Palmariales. The carbohydrate concentration of C. crispus (53.3\% of DM) most likely reflects a high content of carrageenan, as C. crispus cultivated or harvested from Denmark has been found to have a high content (up to $47 \%$ of DM) as well as a high quality of carrageenan [65]. In G. vermiculophylla the $61.9 \%$ carbohydrate of DM indicates a high content of agar. G. vermiculophylla is an invasive species in Europe, where it successfully spreads in shallow estuaries.

Carbohydrate content varies depending on the nutritional status of the algal cell, seasonal and geographical variations, light in particular, generally with accumulation of carbohydrates under high light conditions, and an inverse correlation between $\mathrm{N}$ availability and carbohydrate content exists [65]-[69]. The algae in this study were all harvested in the Danish summer period with maximal light as well as potential nutrient limitation in the inner Danish waters [70]. Thus the high carbohydrate contents, between $50 \%$ and $75 \%$ of the DM, in all studied species except for $P$. rubens (40.2\% of DM), appear to reflect the environmental conditions (Table 2). The relatively low content of carbohydrate in $P$. rubens also as compared to $D$. sanguinea, a species belonging to the same genera and sharing the same habitat was counterbalanced by a relatively high protein content.

The carbohydrate content of the algae species analyzed in this study supports the expectations of high content of hydrocolloids in the already exploited red algae species and point to a potential for a broader commercial exploitation of these species in the North Atlantic region.

\subsection{Carotenoid Composition}

In this study, the concentration of lutein was significantly lower than previously described for in P. palmata (240 mg $\mathrm{kg}^{-1}$ of DM) [71]-[74] and F. lumbricalis (32.8 $\mathrm{mg} \cdot \mathrm{kg}^{-1}$ of DM). $\beta$-carotene is also previously reported in $P$. rubens, D. sanguinea, and C. crispus [75]. As a consequence of the protective function of carotenoids in red algae, accumulation of carotenoids is favored by light, potentially explaining the high $\beta$-carotene content in P. palmata (420 mg $\mathrm{kg}^{-1}$ of DM) in summer as compared to winter( $37 \mathrm{mg} \cdot \mathrm{kg}^{-1}$ of DM) [2]. $\beta$-carotene has an estimated market value of around \$250 million in 2007 and \$261 million in 2010 [76]. Natural $\beta$-carotene consists of an attractive mixture of trans and cis isomers, which can be difficult to obtain by chemical synthesis.

Zeaxanthin and lutein are interesting carotenoids with regard to human and animal diet. These compounds are also used in the cosmetic industry as well as in the feed industry for poultry, pigs, and fish [18] [77]. Moreover, recent studies have shown that a diet rich in these two carotenoids diminished the risk of ophthalmological diseases in human [76].

Common dietary source of carotenoids are colored fruits and vegetables; e.g. spinach is a source of lutein and $\beta$-carotene (62.6 and $44.9 \mathrm{mg} \cdot \mathrm{kg}^{-1} \mathrm{FW}$, respectively) while carrot and mango have high content of $\beta$-carotene (79.7 and $31 \mathrm{mg} \cdot \mathrm{kg}^{-1} \mathrm{FW}$, respectively) [78]. Although fruits and vegetables represent the main part of human carotenoid intake [18], considering the total identified carotenoids in this study, $P$. rubens contained the highest content of carotenoids of nearly $186.1 \mathrm{mg} \cdot \mathrm{kg}^{-1}$ of DM followed by C. crispus and G. vermiculophylla while $P$. 
palmata and A. plicata reached the two lowest levels among the other red macroalgae.

Regarding the animal diet, the required amount of carotenoids can be related to various factors (e.g. species cultivars, diet ingredients, gender, water quality, and seasonal variation). For instance, according to Torrissen and Christiansen [79], carotenoids (canthaxanthin and/or astaxanthin) should be added at a level above $10 \mathrm{mg} / \mathrm{kg}$ of dried fish feed to ensure the well-being of the animal. Regarding the poultry feed, the maximum carotenoids concentration should be set to about $80 \mathrm{mg} / \mathrm{kg}$ of feed for all xanthophylls except canthaxanthin, for which a maximum amount of only $8 \mathrm{mg} / \mathrm{kg}$ is allowed for laying hens and $25 \mathrm{mg} / \mathrm{kg}$ for other poultry [80].

Therefore, as shown in Figure 3, these studied algae represent a relatively high potential to be considered as a direct or as supplementary carotenoid source in human or animal diets in particular in regions where suitable vegetable production or consumption is low. Further cultivation under controlled environmental conditions will have the potential to increase and optimize the content of carotenoids in red algae.

\subsection{Dry Matter, Minerals and Metals}

The red algae investigated had a relatively high DM content. The DM content of P. palmate and C. crispus (29 and $24 \%$ of FW) has been reported by other authors to be in the same range [9] [81].

The ash contents of the nine algae were within the range of ash contents reported from non-coralline red algae [2] [9] [82]-[84]. The ash concentration found in P. palmata was in the lower end of reported values for this species: from $12 \%$ of DM to $37 \%$ of DM [2] [9], having in this respect the largest similarity with material harvested in July from the Irish Sea (11.7\% of DM) [9]. Comparing the here reported ash contents to the ash contents of the same species harvested on Iceland, also in the summer, some species have slightly lower ash contents: A. plicata (13\% versus 30\% - 39\%), D. sanguinea (22.5\% versus $26.2 \%)$, D. carnosa (22.6\% versus $36 \%)$ while other are higher: $P$. rubens (29.1\% versus $28.2 \%)$, O dentata (30.3\% versus $21.0 \%$ ) and some are in the same range: C. crispus (25.1\% versus $23 \%$ - 35\%) [82]. Ruperez [21], Ruperez and Toledano [83] and Pereira and van de Velde [85] reported an ash content of $21 \%$ of DM for C. crispus which is slightly lower than found here in this species (25\% of DM). The ash content depends on the algae species and morphology, but also there is a considerable within-species variation in ash content relating to temporal and spatial factors: The temporal variation reflects responses in growth strategy to availability of light and nutrients, i.e. ash content is inversely correlated to irradiance, but directly correlated to $\mathrm{N}$ availability [86]. Thus, the ash contents of the here analyzed red algae were expected to be low, since they were sampled in late summer with relatively high insolation and low nutrient availability in inner Danish waters [87].

The ash content is inversely correlated to the calorific value of the algae [88]. Thus, the high ash content will act disqualifying in any application of the seaweed biomass with sheer focus on energy, both viewed in a metabolic as well as in a biofuel perspective [69] [89] [90]. However, ash is the mineral residue of organic matter, and minerals are essential for any production of new biomass from agricultural crops to human and livestock animals. Further, the ash from marine seaweeds contain higher amounts of both macro minerals (i.e. Mg, Na, K, $\mathrm{Ca}$ ) and trace metals (i.e. Fe, $\mathrm{Cu}, \mathrm{Zn}$ ) than those reported for edible land plants [91]. In this respect, the value of the mineral fraction will have to be evaluated against the requirements of each specific target organism.

The nine red algae had high concentrations of essential macro minerals and trace elements. Overall, between 1 and $89 \mathrm{~g}$ of dry algae would support the recommended daily mineral intake of human adults if choosing the algae with the highest content of the specific mineral. The only exception is $\mathrm{P}$, where meeting the full daily requirements would require $249 \mathrm{~g}$ of $C$. crispus. Compared to the mineral contents of the conventional human food sources: vegetables, fruits and meat from aquatic or terrestrial animals (Table 5), it is important to keep in mind, that where the values for the conventional food sources are given per $100 \mathrm{~g}$ of $\mathrm{FW}$, the values of the algae are given per $100 \mathrm{~g}$ of DM [14] [92]. The DM content of the algae varied between $18 \%$ and $43 \%$ of FW (Table 1). Accordingly, the mineral concentrations of the fresh algae would be between 2.5 and 5 fold lower than for the dry algae. Taking this into consideration, the mineral contents of the nine red algae are still higher than or as high as the mineral content of the conventional food sources having the highest content of any specific mineral, $\mathrm{P}$ being an exception. In particular, the contents of $\mathrm{Ca}, \mathrm{Fe}, \mathrm{Mn}$ and $\mathrm{Cr}$, are higher in the algae as compared to fruits, vegetables and meats.

Minerals are as essential as to animals as they are to humans and adequate mineral supplement to livestock animals is crucial, in order to have a profitable and efficient farm operation [93] [94]. The nine red algae, in particular $P$. rubens, represent rich sources of essential macro minerals and trace elements. The whole algae, or 
minerals recovered from process streams in simple or complex biorefineries, could constitute mineral supplements, alone or in mixtures, for human food as well as for animal feed [95]. However, for food and feed safety, attention must also be directed to the potentially harmful metals. This will be discussed in Section 4.3.

Macroalgae are found to increase saltiness, umami and enhance flavor [41]. Macroalgae represent a rich source of natural macro minerals and flavor components with a potential for use in sodium replacement strategies. The recommended Na allowances for adults are around $1000-1300 \mathrm{mg} \mathrm{day}^{-1}$ [96] while the daily recommended adult intake is $800 \mathrm{mg} \mathrm{day}^{-1}$ [96] [97]. The average daily sodium intake however, exceeds the recommended level by 2 - 6 times particularly in USA, Canada and Europe [98]. Because the sodium intake and the $\mathrm{Na} / \mathrm{K}$ ratio of diets are causally related to hypertension, an established risk factor for cardiovascular disease, there is serious attention towards reducing intake of sodium [99]. $\mathrm{Na}$ is the main component of salt and estimated seventy-five percent of Na intake is derived from processed food. The Na contents of all the here studied algae were 10 to 100 fold lower than the Na content in table salt and, except for $D$. carnosa, the $\mathrm{Na} / \mathrm{K}$ ratios were below 1.0 in all the red algae studied, in some species down to 0.08 . For comparison, the $\mathrm{Na} / \mathrm{K}$ ratios in olives and sausages are 43.63 and 4.89 , respectively [99].

Salt in food not only provide the salty taste, it is also added for functionality, preservative and as processing aid. Sodium can be replaced with $\mathrm{K}$ and blends of other mineral salts like $\mathrm{Mn}$, Ca, and $\mathrm{Zn}$, however, all have less salty taste than $\mathrm{Na}$ and have bitter notes. Other potentially important minerals for salt replacement blends, like Ca and Zn, were also present in the investigated red algae in relatively high amounts (Table 5), thus further improving the potential of using algae minerals for salt replacements.

Today several seaweed species are included in commercial Na salt reducing blends i.e. two brown macroalgae of the order Laminariales and the red macroalgae P. palmata, which also in this study had the lowest $\mathrm{Na} / \mathrm{K}$ ratio. G. vermiculophylla, A. plicata and O. dentata and all have $\mathrm{Na} / \mathrm{K}$ ratios below 0.5 , and as A. plicata as well as Gracilaria species already are commercially processed for production of hydrocollois (Table 1), these results points to the potential of refining an additional value product from the residues of the processed biomass of these species.

Arsenic, $\mathrm{Cd}$ and $\mathrm{Pb}$ are elements with strict regulations in legislation regarding food and feed. However, the legislations of different countries are not consistent regarding limit values of heavy metals (Figure 1) [2] [100][102]. The concentrations of $\mathrm{Cd}$ and $\mathrm{Pb}$ in C. crispus and $P$. rubens were above limit values for use in food according to legislation in France and Australia/New Zealand (Figure 4(b) and Figure 4(c)). According to French legislation on Cd concentration, all other species would be allowed for food, whereas in Australia/New Zealand the Cd concentrations of $D$. sanguinea and $D$. carnosa would exclude also these two species from use in food. Where Spanish food legislation with a limit value of $5 \mathrm{ppm}$ of $\mathrm{Pb}$ would allow use of all species in food with the exception of C. crispus and P. rubens, only G. vermiculophylla would be allowed for food in France, where $\mathrm{Pb}$ limit value is $1 \mathrm{ppm}$.

All of the nine algae could be applied for production of animal feed according to EU directions. In the EU food regulative, no limit values are set for total As concentrations, but only for the concentration of inorganic As compounds in the algae, which are known to be harmful to humans and other animals [101]. This is also the case for the food legislation in USA, France and Australia/New Zealand, whereas no limit values are set for neither total nor inorganic As in the EU food regulations [2].

Depending on processing and national legislation, the content of specific toxic metals, $\mathrm{As}, \mathrm{Pb}$ and $\mathrm{Cd}$ may become problematic in food and feed applications. However in a biorefinery, each process streams need to be analyzed separately to keep track of metals.

Although temporal and spatial differences have influence on the concentrations of metals in macroalgae [90] [103] [104], the differences in heavy metal concentration of the nine Danish red algae investigated here could not be caused by temporal or spatial variation, since all algae specimens are collected at the same time, and, apart from the G. vermiculophylla, also from the same marine area.

Generally, red algae are considered to contain more As than green algae, but not as much as most brown algae, of which some, e.g. the Hizikia sp., contain very high concentrations of As (up to $141 \mathrm{ppm}$ ) [2]. Red algae have been shown to contain higher proportion of water soluble inorganic As, as compared to green and brown algae [105]. The As values of C. crispus reported here are slightly higher than reported from Spain (12.7 and $16.1 \mathrm{ppm})$ [101]. On the contrary, the concentrations of total As in the Danish P. palmata was lower (4.7 ppm) as compared to the 7.6 and 12.8 ppm reported in the review by Holdt and Kraan [2], or 12.6 and 13.0 ppm as reported by Almela et al. [101]. 
Regarding lead $(\mathrm{Pb})$, the value measured for the here studied $P$. palmata $(1.1 \mathrm{ppm})$ was lower than or equal to values from Japan as reported by Holdt and Kraan [2] (1.1 ppm) and Almela et al. [101] (1.52 ppm), while for $C$. crispus, the $\mathrm{Pb}$ content measured in this study was approximately a factor of 10 higher (6.4 ppm) than for the same species from Spain (0.4 and $0.7 \mathrm{ppm})$. On the other hand, a $\mathrm{Pb}$ concentration in the same range as what was measured in this study was reported for C. crispus from an unpolluted site in Canada (4.6 ppm), whereas at a polluted site in Canada, the Pb concentration in C. crispus was as high as $33.1 \mathrm{ppm}$ [103]. When it comes to $\mathrm{Cd}$, the concentrations measured in the Danish C. crispus and P. palmata were in range with what is reported in the literature: the Danish C. crispus contained 0.5 ppm of Cd as compared to 0.4 and 0.7 ppm [101], and 0.5 to $2.4 \mathrm{ppm}$ in Chondrus from Canada, depending on the degree of pollution (Sharp et al., 1988). The Danish $P$. palmata contained $0.14 \mathrm{ppm}$ of $\mathrm{Cd}$ which is relatively low compared to values reported: $0.70 \mathrm{ppm}$ [2], $0.15 \mathrm{ppm}$ (Japan) and 0.88 ppm (Spain) [101] and 1.49 ppm (Canada) [103].

Regarding other heavy metals, chromium (Cr), $\mathrm{Cu}$ and $\mathrm{Zn}$, it is noteworthy that none of these concentrations were above limit values of any regulations. The values measured in Danish $C$. crispus were in range with values reported from Canadian Chondrus, whereas the value for Nickel (Ni) was approximately twice as high in the Danish Chondrus as compared to the Canadian [103]. The concentrations of Cu and Zn were lower in the Danish Palmaria, than in Palmaria reported from Canada: Cu 3.3 ppm and Zn 81.5 ppm [103]. Regarding the other species analyzed, the contents of heavy metal were in the same range as described for P. palmata and C. crispus, apart from a higher content of $\mathrm{Cu}$ in $\mathrm{D}$. sanguinea, the highest contents of $\mathrm{Zn}$ in $D$. carnosa and the highest content of $\mathrm{Cr}$ in P. rubens.

\subsection{Commercial Perspectives}

The nine North Atlantic red algae described in this study are potential future sources of carotenoids, lipids with a low $\omega 6: \omega 3$ ratio, essential amino acids and different carbohydrates, some with interesting technical and/or bioactive properties. However, there are a number of barriers to overcome in order to commercially exploit macroalgae species, such as these nine species: 1) Stabile and adequate biomass supply, 2) Construction of optimal biorefinery processes and 3) Legislation on novel foods.

Biomass supply: The open sea production of macroalgae is expanding, in particular regarding the large brown algae, the Laminariales [106]. The nine red algae here are all relatively small and slow growing macroalgae (Table 1), and this may become problematic in supplying biomass in volumes required for industrial exploitation. Some of the species occupying the tidal zone and the shallow waters are already being cultivated (Gracilaria sp.) [6] [16] or harvested from natural resources for hydrocolloid production, i.e. A. plicata in Russia and Chile [107] [108], F. lumbricalis in Estonia [109] and beach cast Chondrus in Nova Scotia and Spain [110] [111]. P. palmata (dulse) is harvested for food purposes, and cultivation attempts are also emerging in land based tanks as well as in open sea [86] [112]-[114]. However, the species preferring the deeper waters such as $P$. rubens, $D$. sanguinea, $D$. carnosa and $O$. dentata would be more difficult to access for harvest, but could candidate for tank cultivation. Tank cultivation is more resource demanding, but implies control of environmental parameters, controlling growth. This opens for the potential of optimizing the tissue content of specific compounds of interest through control of environmental conditions [115]. Algae cultivated in tanks may well receive their nutrients from bioremediation of nutrient rich waste streams from land-based aquaculture, agriculture or energy production, improving sustainability as well as economy of the concept, without compromising food or feed safety [116]-[120]. The question of producing sufficient biomass at the right price is always a question of demand and market prices. The annual production of 60.000 dry tons of nori at a value of US\$ 1.5 billion alone in Japan (1994/1995) based on open sea cultivation of a relatively small red algae with a highly complex lifecycle (Porphyra sp.) is an encouraging example of a high demand making a complex production feasible [16] [106] [121].

Biorefinery processes: The construction of biorefinery processes for optimal biomass utilization, maximal sustainability and economic yield is in focus regarding all types of biomass, including macroalgae [122]-[124]. Macroalgae are described as an untapped resource for production of fuels, chemicals, and novel potential high value compounds and processes for their exploitation are emerging [125], e.g. specific enzymes with the capability to function at high salinity are developed [126]. In macroalgae, such as these nine North Atlantic red algae, compounds of interest may be selectively extracted from the biomass, or they may be left in a residual biomass after extraction of other high or low value compounds, i.e. a concentrated protein and mineral residue will be left 
after removal of carbohydrates by hydrolysis and fermentation [124]. The necessity of separating biomass components calls for developments in process technology in order to selectively extract attractive components alone, in sequence or together, as well as to avoid unwanted components such as toxic metals in specific process streams. No significant correlations between the lipid content and the concentrations of toxic metals known to accumulate in fat $(\mathrm{Pb}$ and $\mathrm{Cd})$ was found in the here investigated algae. We also found no significant positive correlations between toxic metals and content of carbohydrate, despite that the sulphate, hydroxyl and carboxyl groups of the algae polysaccharides are strong ion-exchangers, and thus important complexation sites for metal cations [127] [128]. The content of $\mathrm{Pb}$, and other metals, $\mathrm{Mg}$ and $\mathrm{Cr}$, was negatively correlated to the content of carbohydrate, potentially as a consequence of the negative correlation between carbohydrate concentrations and ash content (Table 5). Contents of ash and protein are negatively correlated to carbohydrate content, due to the seasonally fluctuating nature of the carbohydrate pool with light [66].

The correlations described between major biomass components; proteins, ash and carbohydrate, and specific minerals may not necessarily be predictive for what minerals will follow what components in a biorefinery process. The bindings between minerals and protein/carbohydrates in algae are of various nature, and although they may not be uncoupled in mechanic pretreatments, such as milling and air classification as is used for separating starch and protein in legumes [129], they may be cleaved by hydrolysis in thermal, $\mathrm{pH}$ or enzymatic pre-treatments [127] [128]. From this it follows, as an example, that depending on the processes, and sequences of processes applied in a biorefinery, a content of toxic metals above limit values in the initial biomass would not pose a problem for food or feed application of the protein fraction, if the toxic metals could be separated from the high value or protein fraction in one of the early processes. The knowledge of the correlations and the properties of bindings between minerals and biomass components is important in construction of a biorefinery, and also in seeking to increase or decrease the content of specific minerals in the initial biomass in developing cultivation and harvest strategies for specific algae species in tanks on land or in open water scenarios.

Legislation on novel foods: At present however, commercial use of unrefined seaweed products for food are restricted by regulatory terms. Generally, novel foods and food ingredients consisting of isolates from either microorganisms and fungi or algae are under the so-called novel food regulation. The 1997 regulation (EC) No 258/97 stipulates that new foods that have not been marketed in the EU before May 1997 must be pre-approved. Food or ingredients are considered new (and therefore as novel food) if they have not been used for human consumption to a significant degree in the EU before May 1997. Today twenty species of edible seaweeds are recognized by Europe as being safe for human consumption [130]. P. palmata was used only in food supplements before 15 May 1997 and therefore any other food use of this seaweed has to be authorized pursuant according to the EU Novel Food regulation. Furthermore, all other red seaweeds in this study are considered as Novel Food in the EU and require authorization for use in food applications.

The success of feasible exploitation of small and relatively slow growing macroalgae, as these nine species, depends on how barriers such as biomass production, biorefinery construction and legislation are addressed and overcome. Tank cultivation could be a way of optimizing growth rates and biomass composition.

\section{Conclusion}

The species investigated constitute a potential source of health promoting additives for human and animal diets and may be attractive for the food industry as a source of ingredients with high nutritional value. They can provide a dietary alternative to common fruits and vegetables due to their nutritional value. In contrast to the few commercially exploited warm water species of red algae, many red algae are small and relatively slow growing. However, making use of controlled land-based cultivation environments, offers the potential for manipulating cultivation conditions to optimize the yield of biomass or of the specific compounds of interest [115]. In addition, the commercial value of the seaweed species can be enhanced by improving the quality and quantity of the desired compounds through cultivation techniques [115], ecotype selection and through construction of biorefineries making commercial use of more than one seaweed-based product from the biomass produced.

\section{Acknowledgements}

This paper is a part of the research within the Innovation Consortium Natural Ingredients and Green Energy-with sustainable purification technologies (NIGE) financially supported by Danish Agency for Science Technology and Innovation as well as the project Macrofuels, funded by the European Union's Horizon 2020 
research and innovation programme (grant agreement No 654010) to whom the authors are indebted. The authors further thank Theoharis Ouzounis and Tinna Christensen for graphic support, and Peter M. Kofoed, Gitte Jacobsen and Anna Marie Plejdrup, Aarhus University, for valuable assistance in the lab.

\section{References}

[1] Hamed, I., Ozogul, F., Ozogul, Y. and Regenstein, J.M. (2015) Marine Bioactive Compounds and Their Health Benefits: A Review. Comprehensive Review in Food Science and Food Safety, 14, 446-465. http://dx.doi.org/10.1111/1541-4337.12136

[2] Holdt, S.L. and Kraan, S. (2011) Bioactive Compounds in Seaweed: Functional Food Applications and Legislation. Journal of Applied Phycology, 23, 543-597. http://dx.doi.org/10.1007/s10811-010-9632-5

[3] Lee, R. (2008) Phycology. 4th Edition, Cambridge University Press, Cambridge. http://dx.doi.org/10.1017/CBO9780511812897

[4] MacArtain, P., Gill, C.I.R., Brooks, M., Campbell, R. and Rowland, I.R. (2007) Nutritional Value of Edible Seaweeds. Nutrition Reviews, 65, 535-543. http://dx.doi.org/10.1111/j.1753-4887.2007.tb00278.x

[5] Soler-Vila, A., Coughlan, S., Guiry, M.D. and Kraan, S. (2009) The Red Alga Porphyra dioica as a Fish-feed Ingredient for Rainbow Trout (Oncorhynchus mykiss): Effects on Growth, Feed Efficiency, and Carcass Composition. Journal of Applied Phycology, 21, 617-624. http://dx.doi.org/10.1007/s10811-009-9423-z

[6] Bixler, H. and Porse, H. (2011) A Decade of Change in the Seaweed Hydrocolloids Industry. Journal of Applied Phycology, 23, 321-335. http://dx.doi.org/10.1007/s10811-010-9529-3

[7] Galland-Irmouli, A.-V., Fleurence, J., Lamghari, R., Luçon, M., Rouxel, C., Barbaroux, O., Bronowicki, J.-P., Villaume, C. and Guéant, J.-L. (1999) Nutritional Value of Proteins from Edible Seaweed Palmaria palmata (Dulse). The Journal of Nutritional Biochemistry, 10, 353-359. http://dx.doi.org/10.1016/S0955-2863(99)00014-5

[8] Marsham, S., Scott, G.W. and Tobin, M.L. (2007) Comparison of Nutritive Chemistry of a Range of Temperate Seaweeds. Food Chemistry, 100, 1331-1336. http://dx.doi.org/10.1016/j.foodchem.2005.11.029

[9] Morgan, K., Wright, J.C. and Simpson, F.J. (1980) Review of Chemical Constituents of the Red Alga Palmaria palmata (Dulse). Economic Botany, 34, 27-50. http://dx.doi.org/10.1007/BF02859553

[10] Murata, M. and Nakazoe, J. (2001) Production and Use of Marine Algae in Japan. Japan Agricultural Research Quarterly, 35, 281-290.

[11] Marrion, O., Fleurence. J., Schwertz, A., Guéant, J.-L., Mamelouk, L., Ksouri, J. and Villaume, C. (2005) Evaluation of Protein in Vitro Digestibility of Palmaria palmata and Gracilaria verrucosa. Journal of Applied Phycology, 17, 99-102. http://dx.doi.org/10.1007/s10811-005-5154-y

[12] Nordy, A. and Dyerberg, J. (1988) Omega-3 Fatty Acids in Health and Disease. Journal of Internal Medicine, 225, 81-83.

[13] Ransom, A.M. and Boris, W. (2003) Rapid Worldwide Depletion of Predatory Fish Communities. Nature, 423, 280283. http://dx.doi.org/10.1038/nature01610

[14] Tacon, A.G.J. and Metian, M. (2008) Global Overview on the Use of Fish Meal and Fish Oil in Industrially Compounded Aquafeeds: Trends and Future Prospects. Aquaculture, 285, 146-158. http://dx.doi.org/10.1016/j.aquaculture.2008.08.015

[15] Gammone, M.A. and D’Orazio, N. (2015) Anti-Obesity Activity of the Marine Carotenoid Fucoxanthin. Marine Drugs, 13, 2196-2214. http://dx.doi.org/10.3390/md13042196

[16] Zemke-White, W. and Ohno, M. (1999) World Seaweed Utilisation: An End-of-Century Summary. Journal of Applied Phycology, 11, 369-376. http://dx.doi.org/10.1023/A:1008197610793

[17] Takaichi, S. (2011) Carotenoids in Algae: Distributions, Biosyntheses and Functions. Marine Drugs, 9, $1101-1118$. http://dx.doi.org/10.3390/md9061101

[18] Jaswir, I., Noviendri, D., Hasrini, R.F. and Octavianti, F. (2011) Carotenoids: Sources, Medicinals Properties and Their Application in Food and Nutraceutical Industry. Journal of Medicinal Plants Research, 5, 7119-7131.

[19] März, U. (2008) The Global Market for Carotenoids. BCC Research Report FOD025C.

[20] Mageswaran, R. and Sivasubramanian, S. (1984) Mineral and Protein Content of Some Marine Algae from Costal Areas of Northern Sri Lanka. Journal of the National Science Foundation, 12, 179-189

[21] Ruperez, P. (2002) Mineral Content of Edible Marine Seaweeds. Food Chemistry, 79, 23-26. http://dx.doi.org/10.1016/S0308-8146(02)00171-1

[22] Tabarsa, M., Rezaei, M., Ramezanpour, Z. and Waaland, J.R. (2012) Chemical Compositions of the Marine Algae Gracilaria salicornia (Rhodophyta) and Ulva lactuca (Chlorophyta) as a Potential Food Source. Journal of Science 
and Food Agriculture, 92, 2500-2506. http://dx.doi.org/10.1002/jsfa.5659

[23] Percival, E. (1979) Polysaccharides of Green, Red and Brown Seaweeds: Their Basic Structure, Biosynthesis and Function. British Phycological Journal, 14, 103-117. http://dx.doi.org/10.1080/00071617900650121

[24] Necas, J. and Bartosikova, L. (2013) Carrageenan: A Review. Veterinarni Medicina, 58, 187-205.

[25] Middelboe, A.L., Sand-Jensen, K. and Brodersen, K. (1997) Patterns of Macroalgal Distribution in the Kattegat-Baltic Region. Phycologia, 36, 208-219. http://dx.doi.org/10.2216/i0031-8884-36-3-208.1

[26] Culmo, R.F. (2010) Methods of Organic Nitrogen Analysis: Kjeldahl and the EA2410 N Analyzer (Dumas Method) PerkinElmer Publication EAN-8, Washington DC.

[27] Angell, A.R., Mata, L., de Nys, R. and Paul, N.A. (2016) The Protein Content of Seaweeds: A Universal Nitrogento-Protein Conversion Factor of Five. Journal of Applied Phycology, 28, 511-524. http://dx.doi.org/10.1007/s10811-015-0650-1

[28] Jung, S., Rickert, D.A., Deak, N.A., Aldin, E.D., Recknor, J., Johnson, L.A. and Murphy, P.A. (2003) Comparison of Kjeldahl and Dumas Methods for Determining Protein Contents of Soybean Products. Journal of the American Oil Chemists' Society, 80, 1169-1173. http://dx.doi.org/10.1007/s11746-003-0837-3

[29] World Health Organization/Food and Agriculture Organization/United Nations University (2007) Protein and Amino Acid Requirement in Human Nutrition Report of a Joint WHO/FAO/UNU Expert Consultation. WHO Technical Report Series No. 935, Geneva.

[30] Dawczynski, C., Schubert, R. and Jahreis, G. (2007) Amino Acids, Fatty Acids, and Dietary Fibre in Edible Seaweed Products. Food Chemistry, 103, 891-899. http://dx.doi.org/10.1016/j.foodchem.2006.09.041

[31] Razi Parjikolaei, B., Kloster, L.A.B., Rasmussen, M.B., Fretté, X.C. and Christensen, K.V. (2013) Effect of Light Quality and Nitrogen Availability on the Biomass Production and Pigment Content of Palmaria palmata (Rhodophyta). Chemical Engineering Transactions, 32, 967-972.

[32] Gentili, A. and Caretti, F. (2011) Evaluation of a Method Based on Liquid Chromatography-Diode Array Detector-Tandem Mass Spectrometry for a Rapid and Comprehensive Characterization of the Fat-Soluble Vitamin and Carotenoid Profile of Selected Plant Foods. Journal of Chromatography, 1218, 684-697. http://dx.doi.org/10.1016/j.chroma.2010.12.001

[33] Uhe, A.M., Collier, G.R. and O’Dea, K. (1992) A Comparison of the Effects of Beef, Chicken and Fish Protein on Satiety and Amino Acid Profiles in Lean Male Subjects.Journal of Nutrition, 122, 467-472

[34] Misciattelli, L., Hvelplund, T., Weisbjerg, M.R., Madsen, J., Møller, J., Thøgersen, R. and Kjeldsen, A.M. (2002) Fodermidlernes Indhold af Aminosyrer og Aminosyrernes Andel af AAT. Rapport nr. 98. Landbrugets Rådgivningscenter, Denmark.

[35] Mishra, V.K., Temelli, F., Ooraikul, B., Shacklock, P.F. and Craigie, J.S. (1993) Lipids of the Red Alga, Palmaria palmata. Botanica Marina, 36, 169-174. http://dx.doi.org/10.1515/botm.1993.36.2.169

[36] Mouritsen, O.G., Dawczynski, C., Duelund, L., Jahreis, G., Vetter, W. and Schröder, M. (2013) On the Human Consumption of the Red Seaweed Dulse (Palmaria palmata (L.) Weber \& Mohr). Journal of Applied Phycology, 25, 1777-1791. http://dx.doi.org/10.1007/s10811-013-0014-7

[37] Fleurence, J. (1999) Seaweed Proteins: Biochemical, Nutritional Aspects and Potential Uses. Trends in Food Science and Technology, 10, 25-28. http://dx.doi.org/10.1016/S0924-2244(99)00015-1

[38] Marinho, G.S., Holdt, S.L. and Angelidaki, I. (2015) Seasonal Variations in the Amino Acid Profile and Protein Nutritional Value of Saccharina latissima Cultivated in a Commercial IMTA System. Journal of Applied Phycology, 25, 1991-2000. http://dx.doi.org/10.1007/s10811-015-0546-0

[39] Layman, D.K. (2004) Protein Quantity and Quality at Levels above the RDA Improves Adult Weight Loss. The Journal of the American College of Nutrition, 23, 631S-636S. http://dx.doi.org/10.1080/07315724.2004.10719435

[40] McCarty, M.F., Barroso-Aranda, J. and Contreras, F. (2009) The Low-Methionine Content of Vegan Diets May Make Methionine Restriction Feasible as a Life Extension Strategy. Medical Hypotheses, 72, 125-128. http://dx.doi.org/10.1016/j.mehy.2008.07.044

[41] Mouritsen, O.G. (2012) Umami Flavour as a Means of Regulating Food Intake and Improving Nutrition and Health. The Journal of Nutrition Health and Aging, 21, 56-75. http://dx.doi.org/10.1177/0260106012445537

[42] Yaich, H., Garna, H., Besbes, S., Paquot, M., Blecker, C. and Attia, H. (2011) Chemical Composition and Functional Properties of Ulva lactuca Seaweed Collected in Tunisia. Food Chemistry, 128, 895-901. http://dx.doi.org/10.1016/j.foodchem.2011.03.114

[43] Brody, T. (1998) Nutritional Biochemistry. University of California, Berkeley.

[44] Matanjun, P., Mohamed, S., Mustapha, N.M. and Muhammad, K. (2008) Nutrient Content of Tropical Edible Sea- 
weeds, Eucheuma cottonii, Caulerpa lentillifera and Sargassum polycystum. Journal of Applied Phycology, 21, 75-80. http://dx.doi.org/10.1007/s10811-008-9326-4

[45] Kolb, N., Vallorani, L., Milanovi, N. and Stocchi, V. (2004) Evaluation of Marine Algae Wakama (Undaria pinnatifida) and Kombu (Laminaria digitata japonica) as Food Supplements. Food Technology and Biotechnology Journal, 42, 57-61.

[46] Fleurence, J., Morançais, M., Dumay, J., Decottignies, P., Turpin, V., Munier, M., Garcia-Bueno, N. and Jaouen, P. (2012) What Are the Prospects for Using Seaweed in Human Nutrition and for Marine Animals Raised through Aquaculture? Trends in Food Science and Technology, 27, 57-61. http://dx.doi.org/10.1016/j.tifs.2012.03.004

[47] National Research Council (2005) Dietary Reference Intakes for Energy, Carbohydrate, Fiber, Fat, Fatty Acids, Cholesterol, Protein, and Amino Acids (Macronutrients). The National Academies Press, Washington DC.

[48] FAO Statistical Yearbook (Food and Agriculture Organization of the United Nations) (2004) Animal Production and Health Proceedings. FAO, Rome.

[49] Ayadi, F.Y., Rosentrater, K.A. and Muthukumarappan, K. (2012) Alternative Protein Sources for Aquaculture Feeds. Journal of Aquaculture Feed Science and Nutrition, 4, 1-26. http://dx.doi.org/10.3923/joafsnu.2012.1.26

[50] USDA (2013) Agricultural Research Service. National Nutrient Database for Standard Reference, Release 26, Beltsville.

[51] Miles, R.D. and Jacob, J.P. (2011) Fishmeal: Understanding Why This Feed Ingredient Is So Valuable in Poultry Diets (PS30). Institute of Food and Agricultural Sciences, University of Florida, Gainesville.

[52] Millwar, D.J. (2012) Amino Acid Scoring Patterns for Protein Quality Assessment. British Journal of Nutrition, 108, S31-S43. http://dx.doi.org/10.1017/S0007114512002462

[53] Wegner, C.-E., Richter-Heitmann, T., Klindworth, A., Klockow, C., Richter, M., Achstetter, T., Gloeckner, F.O. and Harder, J. (2013) Expression of Sulfatases in Rhodopirellula baltica and the Diversity of Sulfatases in the Genus Rhodopirellula. Marine Genomics, 9, 51-61. http://dx.doi.org/10.1016/j.margen.2012.12.001

[54] Wison, R.P. and Halver, J.E. (1986) Protein and Amino acid Requirement of Fishes. Annual Review of Nutrition, 6, 225-244. http://dx.doi.org/10.1146/annurev.nu.06.070186.001301

[55] Vinoj Kumar, V. and Kaladharan, P. (2007) Amino Acids in the Seaweeds as an Alternate Source of Protein for Animal Feed. Journal of the Marine Biological Association of India, 49, 35-40.

[56] Mabeau, S. and Fleurence, J. (1993) Seaweed in Food Products: Biochemical and Nutritional Aspects. Trends in Food Science and Technology, 4, 103-107. http://dx.doi.org/10.1016/0924-2244(93)90091-N

[57] Morrissey, J., Kraan, S. and Guiry, M.D. (2001) A Guide to Commercially Important Seaweeds on the Irish Coast. Bord Iascaigh Mhara/Irish Sea Fisheris Board, Dublin.

[58] Kumari, P., Kumar, M., Gupta, V., Reddy, C.R.K. and Jha, B. (2010) Tropical Marine Macroalgae as Potential Sources of Nutritionally Important PUFAs. Food Chemistry, 120, 749-757. http://dx.doi.org/10.1016/j.foodchem.2009.11.006

[59] Fleurence, J., Gutbier, G., Mabeau, S. and Leray, C. (1994) Fatty Acids from 11 Marine Macroalgae of the French Brittany Coast. Journal of Applied Phycology, 6, 527-532. http://dx.doi.org/10.1007/BF02182406

[60] van Ginneken, V.J., Helsper, J.P., de Visser, W., van Keulen, H. and Brandenburg, W.A. (2011) Polyunsaturated Fatty Acids in Various Macroalgal Species from North Atlantic and Tropical Seas. Lipid in Health and Disease, $10,104$. http://dx.doi.org/10.1186/1476-511X-10-104

[61] Chuecas, L. and Riley, J.P. (1966) The Component Fatty Acids of Some Seaweed Fats. Journal of the Marine Biological Association UK, 46, 153-159. http://dx.doi.org/10.1017/S0025315400017616

[62] Tasende, M.G. (1999) Fatty Acid and Sterol Composition of Gametophytes and Sporophytes of Chondrus crispus (Gigartinaceae, Rhodophyta). Scientia Marina, 64, 421-426

[63] Dillon, J.T., Aponte, J.C., Tarozo, R. and Huang, Y. (2013) Purification of Omega-3 Polyunsaturated Fatty Acids from Fish Oil Using Silver-Thiolate Chromatographic Material and High Performance Liquid Chromatography. Journal of Chromatography, 1312, 18-25. http://dx.doi.org/10.1016/j.chroma.2013.08.064

[64] Pereira, L. (2011) A Review of the Nutrient Composition of Selected Edible Seaweeds. In: Pomin, V.H., Ed., Seaweed: Ecology, Nutrient Composition and Medicinal Uses, Nova Science Publishers, Inc., Coimbra, 15-47.

[65] Bruhn, A., Rasmussen, M., Olesen, B. and Worm, T. (2008) Kommerciel Dyrkning af Carrageentang (Chondrus crispus) i danske Farvande. Aarhus University, Aarhus.

[66] Black, W.A.P. (1950) The Seasonal Variation in Weight and Chemical Composition of the Common British Laminariaceae. Journal of the Marine Biological Association UK, 29, 45-72. http://dx.doi.org/10.1017/S0025315400056186

[67] Gatenby, C., Orcutt, D., Kreeger, D., Parker, B., Jones, V. and Neves, R. (2003) Biochemical Composition of Three Algal Species Proposed as Food for Captive Freshwater Mussels. Journal of Applied Phycology, 15, 1-11. 
http://dx.doi.org/10.1023/A:1022929423011

[68] Renaud, S. and Luong-Van, J. (2007) Seasonal Variation in the Chemical Composition of Tropical Australian Marine Macroalgae. In: Anderson, R., Brodie, J., Onsøyen, E. and Critchley, A., Eds., Eighteenth International Seaweed Symposium, Developments in Applied Phycology, Vol. 1, Springer Netherlands, Dordrecht, 155-161. http://dx.doi.org/10.1007/978-1-4020-5670-3_20

[69] Bruhn, A., Dahl, J., Nielsen, H.B., Nikolaisen, L.S., Rasmussen, M.B., Markager, S., Olesen, B., Arias, C. and Jensen, P.D. (2011) Bioenergy Potential of Ulva lactuca: Growth Yield, Methane Production and Combustion.Bioresource Technology, 102, 2595-2604. http://dx.doi.org/10.1016/j.biortech.2010.10.010

[70] Lund-Hansen, L.C. (1994) Basisbog i Fysisk-biologisk Oceanografi. GAD.

[71] Sambamurty, A.V.S.S. (2005) A Textbook of Algae. I.K. International Pvt. Ltd., New Delhi.

[72] Lobban, C.S. and Wynne, M.J. (1981) The Biology of Seaweeds. University of California Press, Oakland.

[73] Bjørnland, T. and Aguilar-Martinez, M. (1976) Carotenoids in Red Algae. Phytochemistry, 15, 291-296. http://dx.doi.org/10.1016/S0031-9422(00)89006-8

[74] Bianchi, T.S., Kautsky, L. and Argyrou, M. (1997) Dominant Chlorophylls and Carotenoids in Macroalgae of the Baltic Sea (Baltic Proper): Their Use as Potential Biomarkers. Sarsia, 82, 55-62. http://dx.doi.org/10.1080/00364827.1997.10413637

[75] Marquardt, J. and Hanelt, D. (2004) Carotenoid Composition of Delesseria lancifolia and Other Marine Red Algae from Polar and Temperate Habitats. European Journal of Phycology, 39, 285-292. http://dx.doi.org/10.1080/09670260410001712572

[76] Guedes, A.C., Amaro, H.M. and Malcata, F.X. (2011) Microalgae as Sources of Carotenoids. Marine Drugs, 9, 625644. http://dx.doi.org/10.3390/md9040625

[77] Masetto, A., Flores-Cotera, L.B., Díaz, C., Langley, E. and Sanchez, S. (2001) Application of a Complete Factorial Design for the Production of Zeaxanthin by Flavobacterium sp. Journal of Bioscience and Bioengineering, 92, 55-58. http://dx.doi.org/10.1016/S1389-1723(01)80199-7

[78] O’Neill, M.E., Carroll, Y., Corridan, B., Olmedilla, B., Granado, F., Blanco, I., Van den Berg, H., Hininger, I., Rausell, A.M., Chopra, M., Southon, S. and Thurnham, D.I. (2001) A European Carotenoid Database to Assess Carotenoid Intakes and Its Use in a Five-Country Comparative Study. British Journal of Nutrition, 85, 499-507. http://dx.doi.org/10.1079/BJN2000284

[79] Torrissen, O.J. and Christiansen, R. (1995) Requirements for Carotenoids in Fish Diets. Journal of Applied Ichthyology, 11, 225-230. http://dx.doi.org/10.1111/j.1439-0426.1995.tb00022.x

[80] Britton, G., Liaaen-Jensen, S. and Pfander, H. (2009) Carotenoids: Natural Functions. Vol. 4, Springer, Berlin. http://dx.doi.org/10.1007/978-3-7643-7501-0

[81] Holdt, S.L. (2009) Nutrient Reduction in Aquaculture Waste by Macroalgae Production. PhD Dissertation, University of Southern Denmark, Odense.

[82] Munda, I. (1972) Chemical Composition, Distribution and Ecology of Some Common Benthicmarine Algae from Iceland. Botanica Marina, 15, 1-45. http://dx.doi.org/10.1515/botm.1972.15.1.1

[83] Ruperez, P. and Toledano, G. (2003) Indigestible Fraction of Edible Marine Seaweeds. Journal of Science and Food Agriculture, 83, 1267-1272. http://dx.doi.org/10.1002/jsfa.1536

[84] Kebelmann, K., Hornung, A., Karsten, U. and Griffiths, G. (2013) Thermo-Chemical Behaviour and Chemical Product Formation from Polar Seaweeds during Intermediate Pyrolysis. Journal of Analytical and Applied Pyrolysis, 104, 131-138. http://dx.doi.org/10.1016/j.jaap.2013.08.012

[85] Pereira, L. and van de Velde, F. (2011) Portuguese Carrageenophytes: Carrageenan Composition and Geographic Distribution of Eight Species (Gigartinales, Rhodophyta). Carbohydrate Polymers, 84, 614-623. http://dx.doi.org/10.1016/j.carbpol.2010.12.036

[86] Morgan, K.C. and Simpson, F.J. (1981) The Cultivation of Palmaria palmate. Effect of Light Intensity and Nitrate Supply on Growth and Chemical Composition. Botanica Marina, 24, 273-277. http://dx.doi.org/10.1515/botm.1981.24.5.273

[87] Lund-Hansen, L.C. (2011) Subsurface Chlorophyll Maximum (SCM) Location and Extension in the Water Column as Governed by a Density Interface in the Strongly Stratified Kattegat Estuary. Hydrobiologia, 673, 105-118. http://dx.doi.org/10.1515/botm.1981.24.5.273

[88] Lamare, M.D. and Wing, S.R. (2001). Calorific Content of New Zealand Marine Macrophytes. New Zealand Journal of Marine and Freshwater Research, 35, 335-341. http://dx.doi.org/10.1080/00288330.2001.9517004

[89] Ross, A.B., Jones, J.M., Kubacki, M.L. and Bridgeman, T. (2008) Classification of Macroalgae as Fuel and Its Thermochemical Behavior. Bioresource Technology, 99, 6494-6504. http://dx.doi.org/10.1016/j.biortech.2007.11.036 
[90] Adams, J.M.M., Ross, A.B., Anastasakis, K., Hodgson, E.M., Gallagher, J.A., Jone, J.M. and Donnison, I.S. (2011) Seasonal Variation in the Chemical Composition of the Bioenergy Feedstock Laminaria digitata for Thermochemical Conversion. Bioresource Technology, 102, 226-234. http://dx.doi.org/10.1016/j.biortech.2010.06.152

[91] Jayasree, N.B., Aneesh, T., Prabhakar, V.A. and Anandan, R.B. (2012) GC-MS, HPLC and AAS Analysis of Fatty Acids, Amino Acids and Minerals in Red Algae Ampheroa Anceps. International Journal of Pharmaceutical Sciences, 4, 187-190.

[92] Martinez-Ballesta, M.C., Dominguez-Perles, R., Moreno, D.A., Muries, B., Alcaraz-López, C., Bastías, E., García-Viguera, C. and Carvajal, M. (2010) Minerals in Plant Food: Effect of Agricultural Practices and Role in Human Health. Agronomy for Sustainable Development, 30, 295-309. http://dx.doi.org/10.1051/agro/2009022

[93] Spears, J.W. (1996) Organic Trace Minerals in Ruminant Nutrition. Animal Feed Science and Technology, 58, $151-163$. http://dx.doi.org/10.1016/0377-8401(95)00881-0

[94] Suttle, N.F. (2010) Mineral Nutrition of Livestock. 4th Edition, CABI, London. http://dx.doi.org/10.1079/9781845934729.0000

[95] Nisizawa, K., Noda, H., Kikuchi, R. and Watanabe, T. (1987) TheMain Seaweed Foods in Japan. Hydrobiologia, 151, 5-29. http://dx.doi.org/10.1007/BF00046102

[96] FAO/WHO (2001) Human Vitamin and Mineral Requirements.

[97] Sundhedsministeriet (2003) Sundhedsministeriets Bekendtgørelse 683 af 21.07.2003 om kosttilskud.

[98] Henney, J.E., Taylor, C.L. and Boon, C.S. (2010) Appendix C. International Efforts to Reduce Sodium Consumption. Institute of Medicine (US) Committee on Strategies to Reduce Sodium Intake, The National Academies Press, Washington DC, Bookshelf ID: NBK50961.

[99] Ortega-Calvo, J.J., Mazuelos, C., Hermosin, B. and Saizjimenez, C. (1993) Chemical Composition of Spirulina and Eukaryotic Algae Food Products Marketed in Spain. Journal of Applied Phycology, 5, 425-435. http://dx.doi.org/10.1007/BF02182735

[100] EU (2002) EU Directive 2002/32/EC of the European Parliament and of the Council of 7th May 2002 on Undesirable Substances in Animal Feed.

[101] Almela, C., Clemente, M.J., Velez, D. and Montoro, R. (2006) Total Arsenic, Inorganic Arsenic, Lead and Cadmium Contents in Edible Seaweed Sold in Spain. Food and Chemical Toxicology, 44, 1901-1908. http://dx.doi.org/10.1016/j.fct.2006.06.011

[102] Besada, V., Andrade, J.M., Schultze, F. and Gonzalez, J.J. (2009) Heavy Metals in Edible Seaweeds Commercialised for Human Consumption. Journal of Marine Systems, 75, 305-313. http://dx.doi.org/10.1016/j.jmarsys.2008.10.010

[103] Sharp, G.J., Samant, H.S. and Vaidya, O.C. (1988) Selected Metal Levels of Commercially Valuable Seaweeds Adjacent to and Distant from Point Sources of Contamination in Nova Scotia and New Brunswick. Bulletin of Environmental Contamination and Toxicology, 40, 724-730. http://dx.doi.org/10.1007/BF01697522

[104] Adams, J.M.M., Toop, T.A., Donnison, I.S. and Gallagher, J.A. (2011) Seasonal Variation in Laminaria digitata and Its Impact on Biochemical Conversion Routes to Biofuels. Bioresource Technology, 102, 9976-9984. http://dx.doi.org/10.1016/j.biortech.2011.08.032

[105] Thomson, D., Maher, W. and Foster, S. (2007) Arsenic and Selected Elements in Inter-Tidal and Estuarine Marine Algae, South-East Coast, NSW, Australia. Applied Organometallic Chemistry, 21, 396-411. http://dx.doi.org/10.1002/aoc.1231

[106] FAO (2012) The State of World Fisheries and Aquaculture 2012. FAO Fisheries and Aquaculture Department, Rome, 230.

[107] Mansilla, A., Ávila, M. and Yokoya, N.S. (2012) Current Knowledge on Biotechnological Interesting Seaweeds from the Magellan Region, Chile. Revista Brasileira de Farmacognosia, 22, 760-767. http://dx.doi.org/10.1590/S0102-695X2012005000074

[108] Maggs, C.A. and Pueschel, C.M. (1989) Morphology and Development of Ahnfeltia plicata (Rhodophyta: Proposal of Ahnfeltiales Ord.Nov.1. Journal of Phycology, 25, 333-351. http://dx.doi.org/10.1111/j.1529-8817.1989.tb00131.x

[109] Laos, K. and Ring, S. (2005) Note: Characterisation of Furcellaran Samples from Estonian Furcellaria lumbricalis (Rhodophyta). Journal of Applied Phycology, 17, 461-464. http://dx.doi.org/10.1007/s10811-005-1635-2

[110] Bidwell, R.G.S., McLachlan, J. and Lloyd, N.D.H. (1985) Tank Cultivation of Irish Moss, Chondrus crispus Stackh. Botanica Marine, 28, 87-97. http://dx.doi.org/10.1007/s10811-005-1635-2

[111] Braud, J. (2006) Continuous Seaweed Tank Culture in France: From Chondrus crispus to Coculture of Macroalgae and the Diatom Odontella aurita. In: Critchley, A.T., Ohno, M. and Largo, D.B., Eds., Seaweed Resources of the World, Japan International Cooperation Agency, Yokosuka, 25.

[112] Martinez, B., Viejo, R.M., Rico, J.M., Rodde, R.H., Faes, V.A., Oliveros, J. and Alvarez, D. (2006) Open Sea Cultiva- 
tion of Palmaria palmata (Rhodophyta) on the Northern Spanish Coast. Aquaculture, 254, 376-387. http://dx.doi.org/10.1016/j.aquaculture.2005.10.025

[113] Pang, S.J. and Lüning, K. (2006) Tank Cultivation of the Red Alga Palmaria palmata: Year-Round Induction of Tetrasporangia, Tetraspore Release in Darkness and Mass Cultivation of Vegetative Thalli. Aquaculture, 252, 20-30. http://dx.doi.org/10.1016/j.aquaculture.2005.11.046

[114] Corey, P., Kim, J.K., Duston, J., Garbary, D.J. and Prithiviraj, B. (2013) Bioremediation Potential of Palmaria palmata and Chondrus crispus (Basin Head): Effect of Nitrate and Ammonium Ratio as Nitrogen Source on Nutrient Removal. Journal of Applied Phycology, 25, 1349-1358. http://dx.doi.org/10.1007/s10811-013-9977-7

[115] Hafting, J.T., Critchley, A.T., Cornish, M.L., Hubley, S.A. and Archibald, A.F. (2012) On-Land Cultivation of Functional Seaweed Products for Human Usage. Journal of Applied Phycology, 24, 385-392. http://dx.doi.org/10.1007/s10811-011-9720-1

[116] Msuya, F. and Neori, A. (2008) Effect of Water Aeration and Nutrient Load Level on Biomass Yield, N Uptake and Protein Content of the Seaweed Ulva lactuca Cultured in Seawater Tanks. Journal of Applied Phycology, 20, 10211031. http://dx.doi.org/10.1007/s10811-007-9300-6

[117] Bolton, J., Robertson-Andersson, D., Shuuluka, D. and Kandjengo, L. (2009) Growing Ulva (Chlorophyta) in Integrated Systems as a Commercial Crop for Abalone Feed in South Africa: A SWOT Analysis. Journal of Applied Phycology, 21, 575-583. http://dx.doi.org/10.1007/s10811-008-9385-6

[118] Abreu, M.H., Pereira, R., Yarish, C., Buschmann, A.H. and Sousa-Pinto, I. (2011) IMTA with Gracilaria vermiculophylla: Productivity and Nutrient Removal Performance of the Seaweed in a Land-Based Pilot Scale System. Aquaculture, 312, 77-87. http://dx.doi.org/10.1016/j.aquaculture.2010.12.036

[119] Nielsen, M.M., Bruhn, A., Rasmussen, M.B., Olesen, B., Larsen, M.M. and Moller, H.B. (2012) Cultivation of Ulva lactuca with Manure for Simultaneous Bioremediation and Biomass Production. Journal of Applied Phycology, 24, 449-458. http://dx.doi.org/10.1007/s10811-011-9767-z

[120] Sode, S., Bruhn, A., Balsby, T.S.J., Larsen, M.M., Gotfredsen, A. and Rasmussen, M.B. (2013) Bioremediation of Reject Water from Anaerobically Digested Waste Water Sludge with Macroalgae (Ulva lactuca, Chlorophyta). Bioresource Technology, 146, 426-435. http://dx.doi.org/10.1016/j.biortech.2013.06.062

[121] McHugh, D.J. (2003) A Guide to the Seaweed Industry. FAO Fisheries Technical Paper, Rome, 1-105.

[122] Jung, K.A., Lim, S.R., Kim, Y. and Park, J.M. (2013) Potentials of Macroalgae as Feedstocks for Biorefinery. Bioresource Technology, 135, 182-190. http://dx.doi.org/10.1016/j.biortech.2012.10.025

[123] Ruiz, H.A., Rodriguez-Jasso, R.M., Fernandes, B.D., Vicente, A.A. and Teixeira, J.A. (2013) Hydrothermal Processing, as an Alternative for Upgrading Agriculture Residues and Marine Biomass According to the Biorefinery Concept: A Review. Renewable and Sustainable Energy Reviews, 21, 35-51. http://dx.doi.org/10.1016/j.rser.2012.11.069

[124] Wei, N., Quarterman, J. and Jin, Y.S. (2013) Marine Macroalgae: An Untapped Resource for Producing Fuels and Chemicals. Trends in Biotechnology, 31, 70-77. http://dx.doi.org/10.1016/j.tibtech.2012.10.009

[125] Lorbeer, A.J., Tham, R. and Zhang, W. (2013) Potential Products from the Highly Diverse and Endemic Macroalgae of Southern Australia and Pathways for Their Sustainable Production. Journal of Applied Phycology, 25, 717-732. http://dx.doi.org/10.1007/s10811-013-0003-x

[126] Kern, M., McGeehan, J.E., Streeter, S.D., et al. (2013) Structural Characterization of a Unique Marine Animal Family 7 Cellobiohydrolase Suggests a Mechanism of Cellulose Salt Tolerance. Proceedings of the National Academy of Sciences of the United States of America, 110, 10189-10194. http://dx.doi.org/10.1073/pnas.1301502110

[127] Crist, R.H., Martin, J.R., Guptill, P.W., Eslinger, J.M. and Crist, D.R. (1990) Interaction of Metals and Protons with Algae. 2. Ion Exchange in Adsorption and Metal Displacement by Protons. Environmental Science and Technology, 24, 337-342. http://dx.doi.org/10.1021/es00073a008

[128] Vasconcelos, M.T.S.D. and Leal, M.F.C. (2001) Seasonal Variability in the Kinetics of Cu, Pb, Cd and Hg Accumulation by Macroalgae. Marine Chemistry, 74, 65-85. http://dx.doi.org/10.1016/S0304-4203(00)00096-7

[129] Tyler, R.T., Youngs, C.G. and Sosulski, F.W. (1981) Air Classification of Legumes. 1. Separation Efficiency, Yield, and Composition of the Starch and Protein Fractions. Cereal Chemistry, 58, 144-148.

[130] EU (1997) EU Novel Food Catalogue.

[131] Lísa, M., Netušilová, K., Franěk, L., Dvořáková, H., Vrkoslav, V. and Holčapek, M. (2011) Characterization of Fatty Acid and Triacylglycerol Composition in Animal Fats Using Silver-Ion and Non-Aqueous Reversed-Phase High-Performance Liquid Chromatography/Mass Spectrometry and Gas Chromatography/Flame Ionization Detection. Journal of Chromatography A, 1218, 7499-7510. http://dx.doi.org/10.1016/j.chroma.2011.07.032

[132] Landim, A.V., Cardoso, M.T., Castanheira, M., Fioravanti, M.C., Louvandini, H. and McManus, C. (2011) Fatty Acid Profile of Hair Lams and Their Crossbreds Slaughtered at Different Wrights. Tropical Animal Health and Production, 


\section{8, 1561-1566. http://dx.doi.org/10.1007/s11250-011-9842-0}

[133] Hoekman, S.K., Broch, A., Robbins, C., Ceniceros, E. and Natarajan, M. (2012) Review of Biodiesel Composition, Properties, and Specifications. Renewable \& Sustainable Energy Reviews, 16, 143-169. http://dx.doi.org/10.1016/j.rser.2011.07.143

[134] Grunewald, N., Groth, I. and Alban, S. (2009) Evaluation of Seasonal Variations of the Structure and Anti-Inflammatory Activity of Sulfated Polysaccharides Extracted from the Red Alga Delesseria sanguinea (Hudson) Lamouroux (Ceramiales, Delesseriaceae). Biomacromolecule, 10, 1155-1162. http://dx.doi.org/10.1021/bm8014158

[135] Tariq, V.N. (1991) Antifungal Activity in Crude Extracts of Marine Red Algae. Mycological Research, 95, $1433-1435$. http://dx.doi.org/10.1016/S0953-7562(09)80398-5

[136] Lahaye, M. and Vigouroux, J. (1992) Liquefaction of Dulse (Palmaria palmata (L.) Kuntze) by a Commercial Enzyme Preparation and a Purified Endo, $\beta$-1,4-D-xylanase. Journal of Applied Phycology, 4, 329-337. http://dx.doi.org/10.1007/BF02185790

[137] Dauguet, J.C., Bert, M., Dolley, J. and Bert, J.J. (1993) Sterols of Phycodrys rubens (Delesseriaceae, Ceramiales). Cryptogamie. Algologie, 14, 99-104.

[138] Potin, P., Patier, P., Floch, J.Y., Yvin, J.C. and Rochas, C. (1992) Chemical Characterization of Cell-Wall Polysaccharides from Tank-Cultivated and Wild Plants of Delesseria sanguinea (Hudson) Lamouroux (Ceramiales, Delesseriaceae): Culture Patterns and Potent Anticoagulant Activity. Journal of Applied Phycology, 4, 119-128. http://dx.doi.org/10.1007/BF02442460

[139] Martin, G., Paalme, T. and Torn, K. (2006) Growth and Production Rates of Loose-Lying and Attached Forms of the Red Algae Furcellaria lumbricalis and Coccotylus truncatus in Kassari Bay, the West Estonian Archipelago Sea. Hydrobiologia, 554, 107-115. http://dx.doi.org/10.1007/s10750-005-1010-y

[140] van de Poll, W.H., Eggert, A., Buma, A.G.J. and Breeman, A.M. (2001) Effects of UV-Binduced DNA Damage and Photoinhibition on Growth of Temperate Marine Red Macrophytes: Habitat-Related Differences in UV-B Tolerance. Journal of Phycology, 37, 30-37. http://dx.doi.org/10.1007/s10750-005-1010-y

[141] Gordillo, F.J.L. (2008) Ecophysiological Changes in Arctic Seaweeds Triggered by Rising Temperature and Dissolved $\mathrm{CO}_{2}$ (SEATEC). University of Malaga, Malaga. 